\title{
A review on high stiffness aluminum-based composites and bimetallics
}

\author{
Sajjad Amirkhanlou, and Shouxun Ji
}

\section{QUERY SHEET}

This page lists questions we have about your paper. The numbers displayed at left can be found in the text of the paper for reference. In addition, please review your paper as a whole for correctness.

Q1. A disclosure statement reporting no conflict of interest has been inserted. Please correct if this is inaccurate.

Q2. Please provide volume number and page range for the reference "4".

Q3. Please provide publisher location for the references "15, 16, 65, 84, 85".

Q4. Please expand all author names for all references instead of using "et al.".

Q5. Please provide publisher details for the reference "64".

\section{TABLE OF CONTENTS LISTING}

The table of contents for the journal will list your paper exactly as it appears below:

\section{A review on high stiffness aluminum-based composites and bimetallics}

Sajjad Amirkhanlou, and Shouxun Ji 


\title{
A review on high stiffness aluminum-based composites and bimetallics
}

\author{
Sajjad Amirkhanlou and Shouxun Ji
}

Brunel Centre for Advanced Solidification Technology (BCAST), Institute of Materials and Manufacturing, Brunel University London, Uxbridge, United Kingdom

\begin{abstract}
The Young's modulus of aluminum-based materials is one of the most important mechanical properties in controlling structural performance. The improvement of the Young's modulus of castable aluminum-based materials is essential for improving their competiveness in light weighting structural applications. Currently, there are limited options for cast aluminum alloys with outstanding Young's modulus. Also, for further stiffness improvement and thereby weight lightening, in-depth understanding of the relevant mechanisms for modulus improvement in aluminum alloys is necessary. This review focuses on the Young's modulus of cast aluminum-based composites, as well as aluminum alloys reinforced with continuous metallic fibers (bimetallic materials). The effect of different chemical elements in cast alloys, the constituents of in-situ and ex-situ formed aluminum matrix composites, and the wire-enhanced bimetallic materials on the Young's modulus of aluminum-based materials are reviewed. The Young's modulus of cast aluminum alloys can be improved by: (a) introducing high modulus reinforcement phases - such as $\mathrm{TiB}_{2}, \mathrm{SiC}, \mathrm{B}_{4} \mathrm{C}$, and $\mathrm{Al}_{2} \mathrm{O}_{3}$ - into aluminum by in-situ reactions or by ex-situ additions; and (b) forming bimetallic materials with metallic wire/bar reinforcement in the aluminum matrix. The performance of a stiff aluminum alloy depends on the volume fraction, size, and distribution of the high modulus phases as well as the interface between reinforcement and Al matrix. One of the major concerns is the reduction of the ductility of castings after adding specific high modulus phases to increase the Young's modulus. Further research into the improvement of Young's modulus and the ductility of aluminum alloys is necessary through proper selection of reinforcement, optimizing interface, and distribution of reinforcement.
\end{abstract}

\section{KEYWORDS}

Cast aluminum alloys;

stiffness; high modulus

materials; bimetallic

materials; metal matrix

composites; light metals

1. Introduction
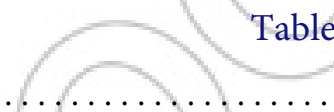

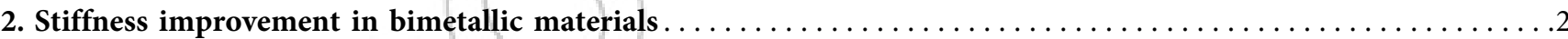

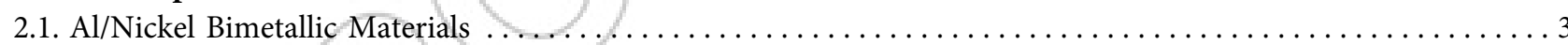

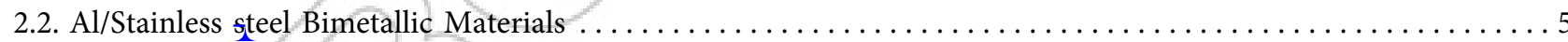

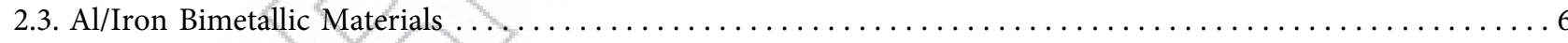

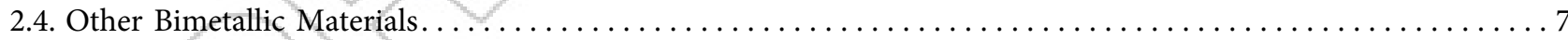

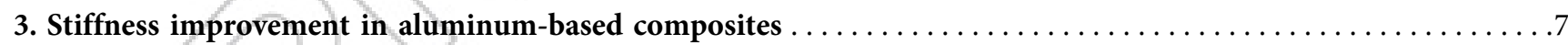

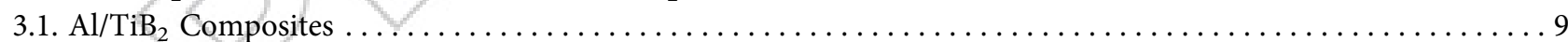

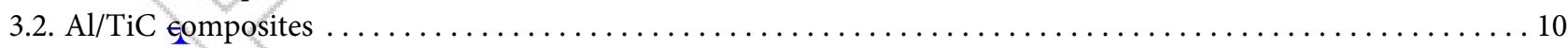

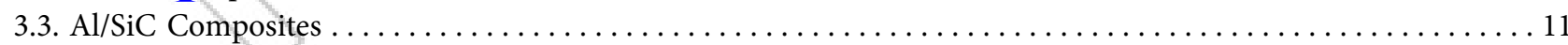

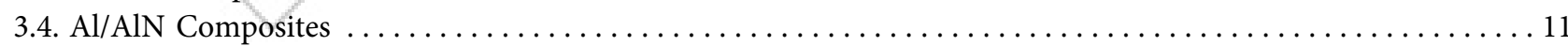

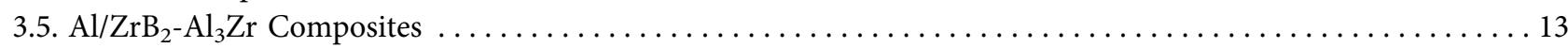

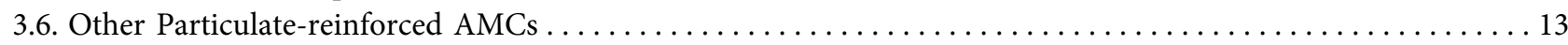

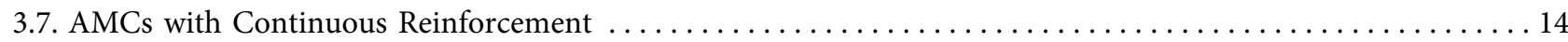

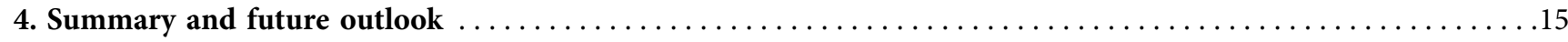

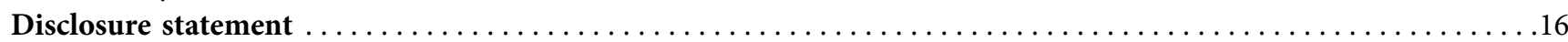

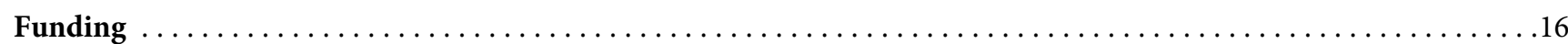

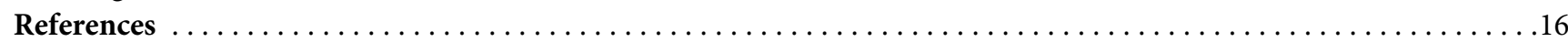




\section{Introduction}

Weight reduction through applying aluminum structural components in aerospace and automobile industries is one of the most promising ways to decrease energy and fuel consumption. ${ }^{1,2}$ These structural components, in particular shaped castings, are usually designed on the criteria of either yield strength or stiffness. ${ }^{3,4}$ When the yield strength is used as the design criterion, aluminum alloys with much higher strength than pure aluminum are commercially available and these can be selected for industrial applications. ${ }^{5,6}$ However, when the stiffness is used as the design criterion, there are limited options for the aluminum alloys with significantly increased stiffness than that of aluminum. ${ }^{7,8}$ There is a lack of thorough understanding of the stiffness of aluminum alloys and aluminum-based materials that can be used to make castings. Moreover, some of the strengthening mechanisms, which result in a significant improvement in yield strength, have no obvious effect on the stiffness. ${ }^{9,10}$ This has limited the applications of aluminum alloys in the shaped castings and components that require high modulus to achieve further weight reduction in the aluminum structures.

As the intrinsic property of materials, the Young's modulus of cast aluminum alloys can only be marginally influenced by manipulating traditional metallurgical variables that can change the microstructure of aluminum alloys significantly. ${ }^{11,12}$ Minor changes of microstructure by alloying elements as well as deformation and heat treatment processes cannot improve the stiffness of Al-based materials. Lucena et al. ${ }^{13}$ studied the variation in the Young's modulus of AA1050 ( $>99.5 \%$ Al) with cold plastic deformation (tension test). Young's modulus decreased from $69 \mathrm{GPa}$ (initial material) to $63 \mathrm{GPa}(2.5 \%$ strain), then increased to $65 \%$ (6\% strain) and finally stabilized to $66 \mathrm{GPa}$ (13\% strain). Villuendas et al. ${ }^{14}$ showed that the Young's modulus of AA2024 and AA7075 in solution treated, deformed, and aged alloys were slightly lower $(<2 \%$ reduction) than those of the undeformed specimens. Despite of deformation and heat treatment, chemical composition and phase constituents are two main factors governing the stiffness properties of casting alloys. ${ }^{15}$ Processes that can change the microstructure significantly can alter the Young's modulus. The high concentration of alloying elements can have perceptible influence through the contribution in bind interaction. In fact, the high modulus phases can be introduced into the aluminum matrix through major addition of alloying elements and/or ceramic particles. ${ }^{16,17}$ The addition of ceramics into the aluminum matrix to form aluminum matrix composites (AMCs)

has been the topic of numerous investigations, ${ }^{18,19}$ in which the high modulus phases can be generated by in-situ reactions with different metallic elements or nonmetallic ceramic compounds, or by direct injection of foreign phases. ${ }^{20,21}$ In a similar way, bimetallic materials such as wire-reinforced metallic structures can be recognized as a special category of composites in macroscale, ${ }^{22}$ which can be used for an effective increase of Young's modulus. In general, the Young's modulus of cast aluminum alloys is less sensitive to alloying as compared to the stiffer reinforcement in AMCs or bimetallic materials.

The understanding of the successes and challenges in the stiffness of materials can serve as a guidepost for where future work is needed in order to effectively propel the technology development. Therefore, this review focuses on the Young's modulus of cast aluminum alloys, composites, and bimetallic materials and their fabrication processes, aiming to provide a snapshot of the current progress on cast aluminum alloys for improving their Young's modulus. The paper is outlined as follows. Section two summarizes the effect of wire reinforcement on the Young's modulus of aluminum-based bimetallic materials. The properties of commonly used reinforcements are discussed in association with the merits and limitations of processing. Section three focuses on the stiffness improvement by in-situ and ex-situ composites. A discussion on the processing, microstructure, and Young's modulus of the in-situ and ex-situ reinforcement - including $\mathrm{TiB}_{2}$, TiC, $\mathrm{AlN}, \mathrm{ZrB}_{2}$, and $\mathrm{Al}_{2} \mathrm{O}_{3}$ - in cast $\mathrm{Al}$ alloys is provided. Section five ends the paper with the summary and future outlook.

\section{Stiffness improvement in bimetallic materials}

Bimetallic materials can be considered as a special type of composites, in which continuous metallic wires/bars are used as skeletons or frames for overcasting with conventional casting methods. ${ }^{23,24}$ Overcasting is casting process when liquid molten metal is poured onto a solid-state metal/ceramic. ${ }^{25}$ The network structures, or skeletons or continuous fibers, have been extensively used in polymer/ceramic matrix composites, ${ }^{26,27}$ but the bimetallic materials are particularly used in this review for the metal-metal mixture made by casting, in which the metallic skeletons or frames made by high modulus reinforcement are covered partially or completely by aluminum alloys. The skeleton preforms not only provide a 
(a)

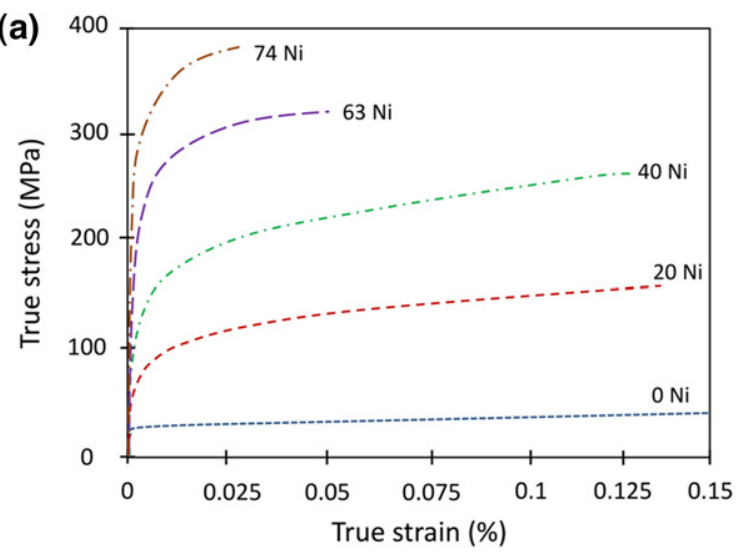

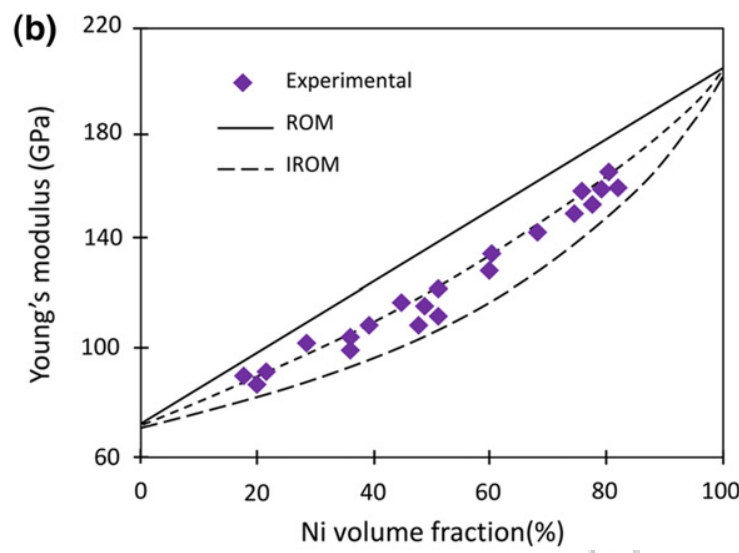

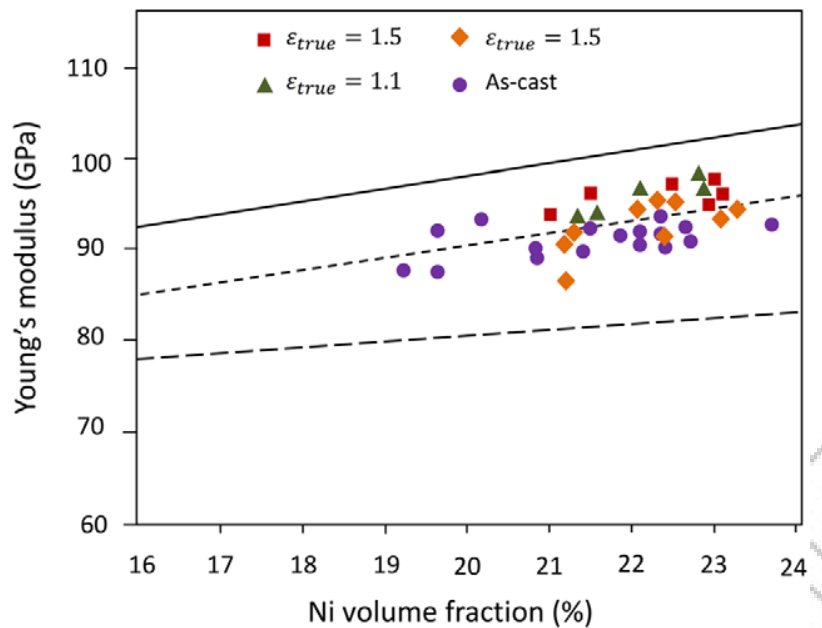

Figure 2. Young's modulus of as-cast and deformed $\mathrm{Al} / \mathrm{Ni}$ bimetallic materials. ${ }^{37}$

controlled and stable reinforcement, but also offer new architectures and increase the Young's modulus and provide more effective load transfer. ${ }^{28}$

Compared with the reinforcements such as particles, ${ }^{29}$ whiskers, ${ }^{30}$ short fibers, and continuous fibers $^{31}$ used in AMCs, the metallic network structures or skeletons are likely desirable to perform more efficiently, especially in reinforcing the local area of a cast component with relatively low cost and more flexible in manufacturing through casting processes. AMCs usually present low fracture toughness due to the brittle nature of reinforcement, which restricts their applications. The network structure fabricated by metallic wires can be $1 \mathrm{D}, 2 \mathrm{D}$, or $3 \mathrm{D}$ interconnected structures with appropriate surface treatment, which enhance the interface bonding during casting process and improve the modulus without scarifying ductility and toughness. The network structure and the interface are two critical aspects for the manufacturing of sound bimetallic materials. According to the nature of metals, nickel and steel/iron are two popular options for making network structure in the existing literature. Limited studies for other potential metals have been performed.

\subsection{Al/Nickel Bimetallic Materials}

The interconnected network made by continuous wires of Inconel 601 (12 $\mu \mathrm{m}$ diameter) has been used to reinforce aluminum alloys through sintering the wires before infiltrating aluminum melt by squeeze casting. ${ }^{32,33}$ Figure $1(\mathrm{a})$ shows the stress-strain curves for pure $\mathrm{Al}$ and $\mathrm{Al} / \mathrm{Ni}$ bimetallic materials. ${ }^{35}$ The remarkable improvement of ductility is attributed to the absence of defects in the microstructure of the $\mathrm{Al} /$ $\mathrm{Ni}$ bimetallic materials. Figure 1(b) shows the variation of the Young's modulus of $\mathrm{Al} / \mathrm{Ni}$ bimetallic materials as a function of the volume fraction of the reinforced wires, in which the upper and lower curves correspond to the ROM and IROM models computed using $\mathrm{E}_{\mathrm{Al}}=70 \mathrm{GPa}$ and $\mathrm{E}_{\mathrm{In} 601}=206 \mathrm{GPa}$. The Young's modulus increases in the bimetallic materials with increasing the $\mathrm{Ni}$ volume fraction. Most of the results are close to the average between the two bounds defined by the ROM and IROM models. The Young's modulus can reach a level of $95 \mathrm{GPa}$, while the elongation is still more than $7 \%$ in the $\mathrm{Al} / 30$ vol.\% $\mathrm{Ni}$ wire-reinforced bimetallic materials. ${ }^{36}$ The deformation has no significant effect on the Young's modulus of the $\mathrm{Al} / \mathrm{Ni}$ bimetallic materials, as shown in Figure 2. The Young's modulus under as-cast condition is very similar to that under as-deformed condition, ${ }^{34}$ which is due to the fact that heat treatment and metal forming do not change the volume fraction of high modulus phases in the aluminum alloys and thereby negligible change has been reported after these processes. ${ }^{14}$

The interface between $\mathrm{Al}$ matrix and wire reinforcement plays a critical role in stiffness 

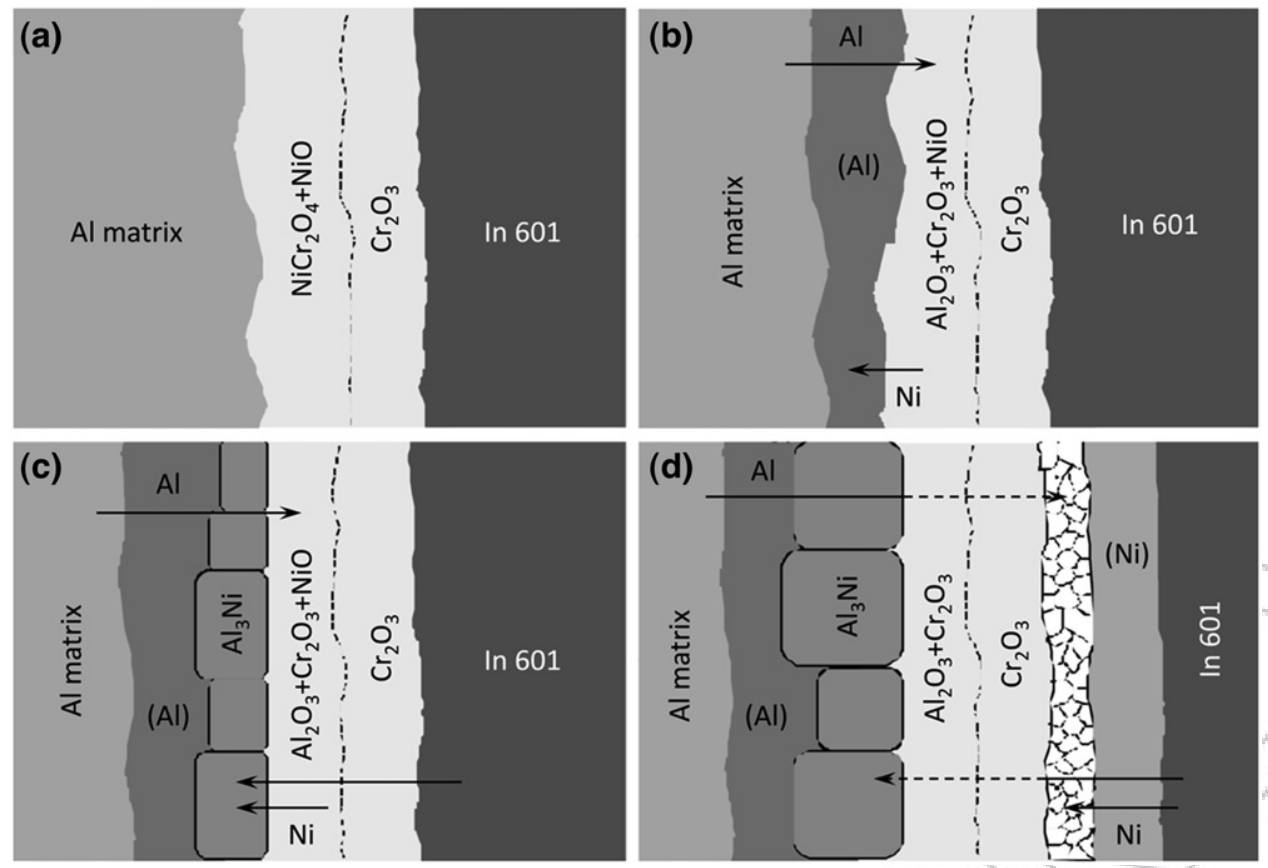

Figure 3. Mechanism of nucleation and growth of the intermetallic nodules in the Al/Ni bimetallic materials. ${ }^{40}$

enhancement in the bimetallic materials. Salmon et al. ${ }^{38}$ investigated the influence of the oxidation of $\mathrm{Ni}$ wire on the mechanical properties of $\mathrm{Al} / \mathrm{Ni}$ bimetallic materials and found that an optimum stress and ductility can be obtained with an appropriate oxidation of the Ni alloy during sintering. The mechanical properties can be justified as a result of compromise between the sufficient oxide roughness to the desired wire/matrix adhesion and the limited oxidation to prevent an excessive degradation of the wires. The tensile properties of $\mathrm{Al} / \mathrm{Ni}$ bimetallic materials are sensitively affected by the nature of the layer of oxide barrier which protects the wires from the reaction with the matrix during casting. ${ }^{39}$ The ductility of $\mathrm{Al} /$ Ni bimetallic materials can be improved by tuning the annealing conditions during the sintering process and introducing a barrier layer into the $\mathrm{Al} / \mathrm{Ni}$ interface. It

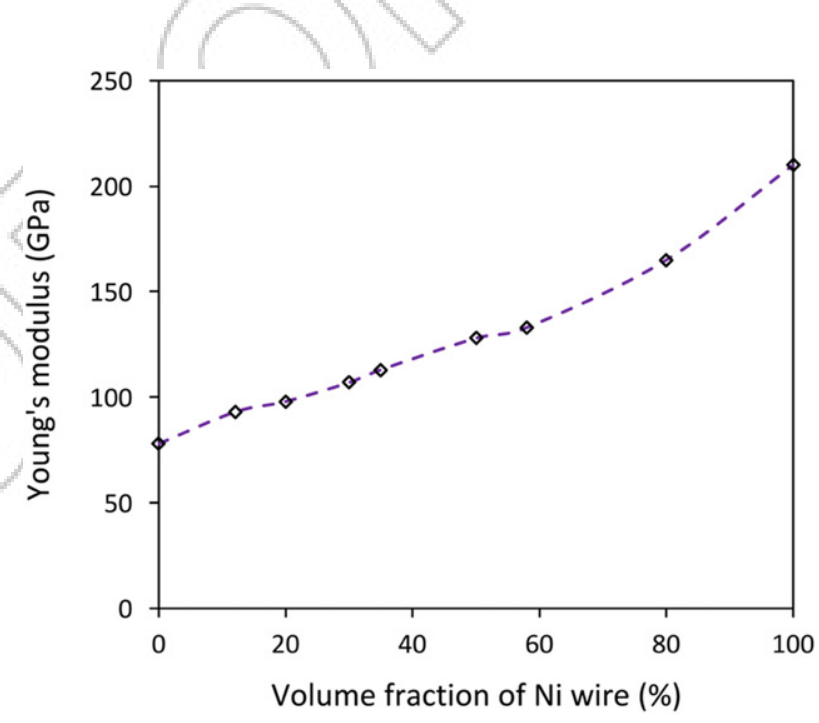

Figure 4. Young's modulus of Al-13 wt.\% Si alloy reinforced with Ni wires. ${ }^{41}$

Young's modulus can be significantly increased with the increment of Ni contents in the Al-13 wt.\% Si alloy. Comparing the results shown in Figures 1-4, the reinforcement is more effective in the alloys than that in the pure aluminum.

Two parameters are important in the processing of bimetallic materials. One is the initiation of a reaction between the wires and the matrix, which is normally controlled by the cooling rate during casting, and the second is the stability of the oxide passivation barrier at the surface of the wires. The stability of the oxide barrier can be increased either by a pre-oxidizing treatment for the reinforcement wires or by specified by Inconel 601 wires. As shown in Figure 4, the 

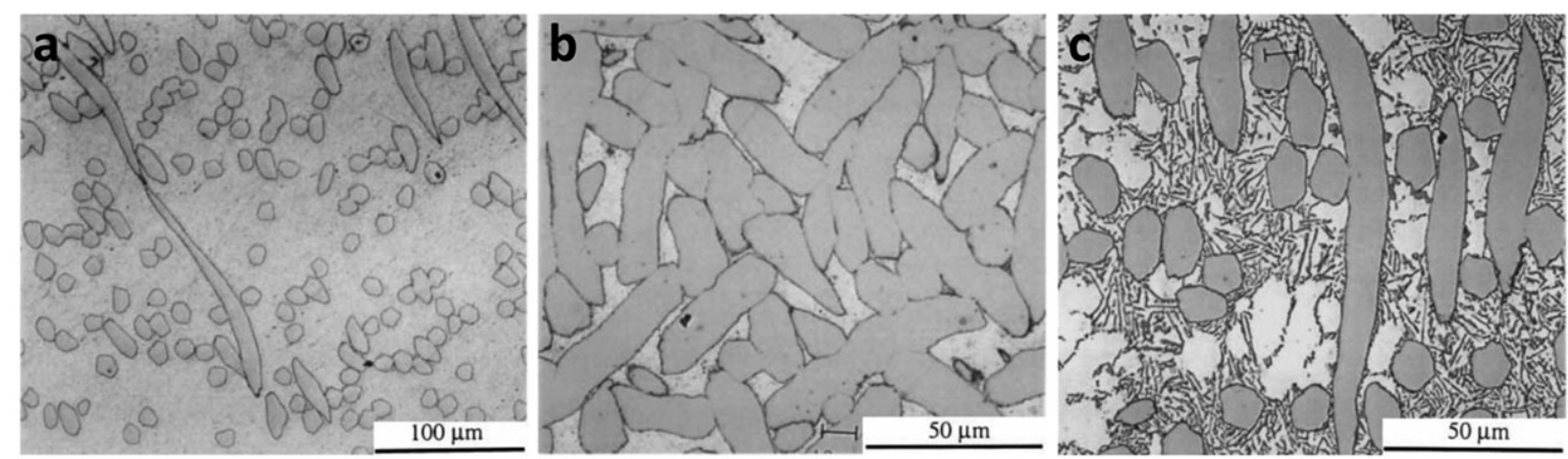

Figure 5. Optical micrograph of (a) $\mathrm{Al} / 20 \mathrm{vol} . \% \mathrm{Ni}$, (b) $\mathrm{Al} / 80 \mathrm{vol} . \% \mathrm{Ni}$, and (c) $\mathrm{Al}-13 \mathrm{Si} / 20$ vol.\% $\mathrm{Ni}$ bimetallic materials. ${ }^{41}$
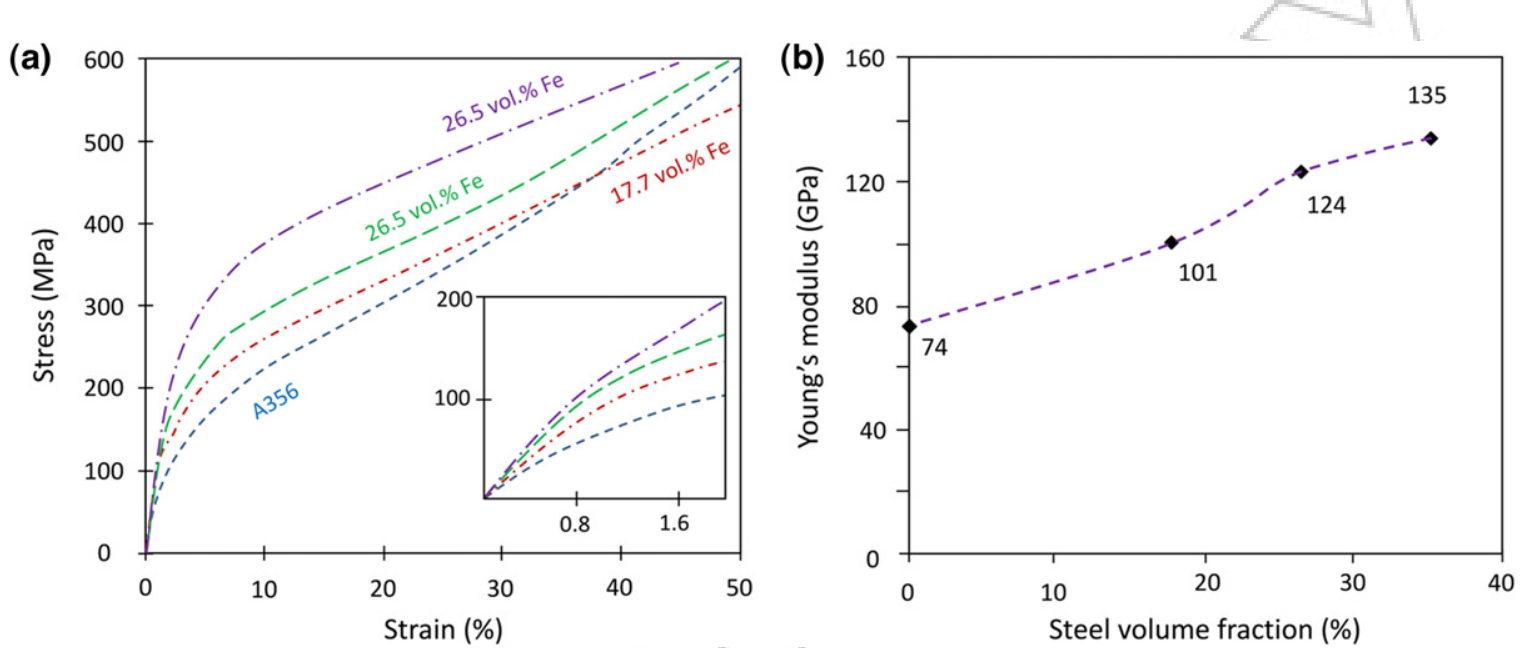

Figure 6. (a) Stress-strain curves for the bimetallic materials with different volume fraction of steel wires and (b) the corresponding Young's modulus. ${ }^{40}$

alloying elements to decrease the melting temperature of the matrix. The Cr-rich passivation layer on the surface of IN601 can increase the refractoriness in oxidizing environments. This will reduce the reactivity of the wires toward $\mathrm{Al}$ during overcasting. On the other hand, when the matrix is Al-Si alloys, the Si platelets tend to nucleate preferentially at the wire/matrix interface. This phenomenon has been reported to occur commonly in the composites with $\mathrm{SiC}, \mathrm{Al}_{2} \mathrm{O}_{3}$, or $\mathrm{TiB}_{2}$ reinforcements with the particle pushing mechanism. ${ }^{40}$ Therefore, the presence of $\mathrm{Si}$ in $\mathrm{Al}$ induces a strong reduction of the reactivity between the wires and the matrix, which can result in the further improvement in the Young's modulus of the bimetallic materials. As illustrated in Figure 5, no reaction compound in the matrix could be detected in the bimetallic materials processed using optimized pre-oxidized preforms. ${ }^{15}$ It is necessary to note that the interface requirement is different between the AMCs and the bimetallic materials. In AMCs, the interface is preferred to be clean without any reaction. However, a limited reaction layer is preferred in the bimetallic materials for the better mechanical properties.

\subsection{Al/Stainless steel Bimetallic Materials}

Fabrication of aluminum-based bimetallic materials reinforced by $3 \mathrm{D}$ entangled stainless steel wires has been successful using mono-filament annealed 304 stainless steel wires with $100 \mu \mathrm{m}$ in diameter in a preform structure. ${ }^{34,36}$ The continuous wire was firstly coiled around a $ø 1.5 \mathrm{~mm}$ rod to form spring-like segments, which were subsequently stretched and entangled to form a pre-compacted sample for squeeze casting. The nominal compressive stress-strain curves are shown in Figure 6. The yield strength and the Young's modulus of the bimetallic material increase as the volume fraction of the steel wires increases. The yield strength can reach $318 \mathrm{MPa}$ for the bimetallic material reinforced with the 35.4 vol.\% of entangled stainless steel preform. The Young's modulus of $\mathrm{Al} / 26$ vol.\% stainless steel bimetallic material is $124 \mathrm{GPa}$, which shows a significant improvement in comparison with that of the A356 alloy.

The microstructures of A356 matrix alloy reinforced by $3 \mathrm{D}$ entangled wires are shown in Figure 7. 
The wire segments show different morphologies in the matrix with homogeneous distribution. When the process is properly controlled, the introduction of wires has little influence on the microstructures of the matrix. In optimum conditions, the cohesion between the matrix and the wires is well obtained and no obvious traces of interface reaction can be observed because of the prevention of the reaction by the oxide barrier layer on the metallic wire, ${ }^{42}$ which offers the best improvement of the Young's modulus.

The network structure of stainless steel can also be fabricated by sintering the wires before infiltrating the aluminum alloys through casting. The improvement of the Young's modulus without significantly scarifying the ductility is achievable in bimetallic materials reinforced by an interconnected network of continuous wires of stainless steel. ${ }^{41}$ Figure 8 shows the Young's modulus and the density of $\mathrm{Al} /$ steel cast bimetallic materials versus the volume fraction of the interconnected network of continuous wires. It is

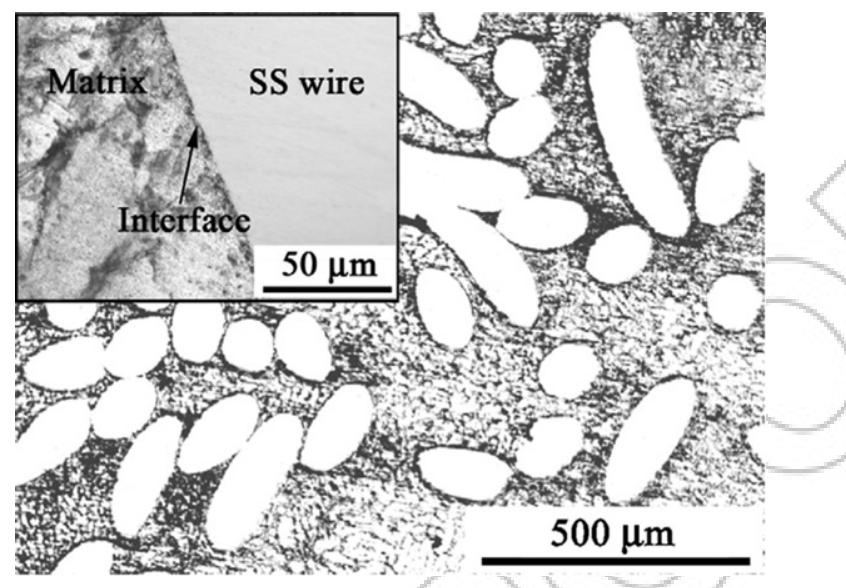

Figure 7. Microstructures of the A356 alloys reinforced by a preform with entangled 304 stainless steel wire at 17.7 vol. $\%{ }^{40}$

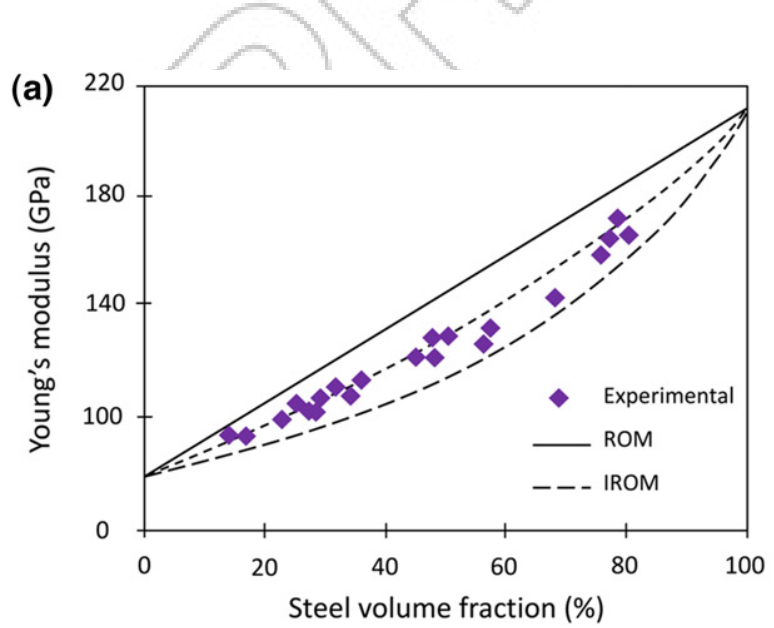

obvious that the Young's modulus increases with increasing steel volume fraction. When the interconnected structures are used to improve the Young's modulus, the selection of the desirable volume fraction of the reinforcement and the structural design should be considered as important criteria.

\subsection{Al/Iron Bimetallic Materials}

Interconnected wires in the form of three-dimensional preforms are an approach to improve the Young's modulus by continuous steel/iron reinforcement in $\mathrm{Al}$ alloys. Gupta et al. ${ }^{37,40}$ fabricated several types of $3 \mathrm{D}$ preforms using the galvanized AISI 1008 wire of $0.8 \mathrm{~mm}$ diameter coated by 10.8 vol.\% zinc. The geometries of the two types of reinforcement preforms are shown in Figure 9.

The mechanical properties for the Al/Fe bimetallic materials with AA1050 (99.5 wt.\% Al) as the matrix are shown in Table 1. The incorporation of 3-5 vol.\% of iron wires as reinforcement increases the Young's modulus, yield strength, and ultimate tensile strength, but degrades the ductility. The Young's modulus is $88 \mathrm{GPa}$ and the specific stiffness is $30.3 \mathrm{GPa} /\left(\mathrm{g} / \mathrm{cm}^{3}\right)$ for the $\mathrm{Al} / 5$ vol.\% $\mathrm{Fe}$ bimetallic materials, which is much higher than that of the monolithic Al alloys. The measured Young's modulus of the bimetallic Al/ $\mathrm{Fe}$ materials exceeds the ROM prediction. This has been attributed to the combined effect of redistributing the fiber stress from the three-dimensional interconnected nature and the limited presence of the intermetallics at the interface. ${ }^{45}$ Gupta et al. ${ }^{40}$ fabricated aluminum-based bimetallic materials containing titanium particles and iron mesh (continuous) reinforcement. Ti particles and the galvanized iron wire mesh ( 0.4 vol.\% zinc and $0.8 \mathrm{~mm}$ wire diameter $)$ are utilized as the continuous/interconnected

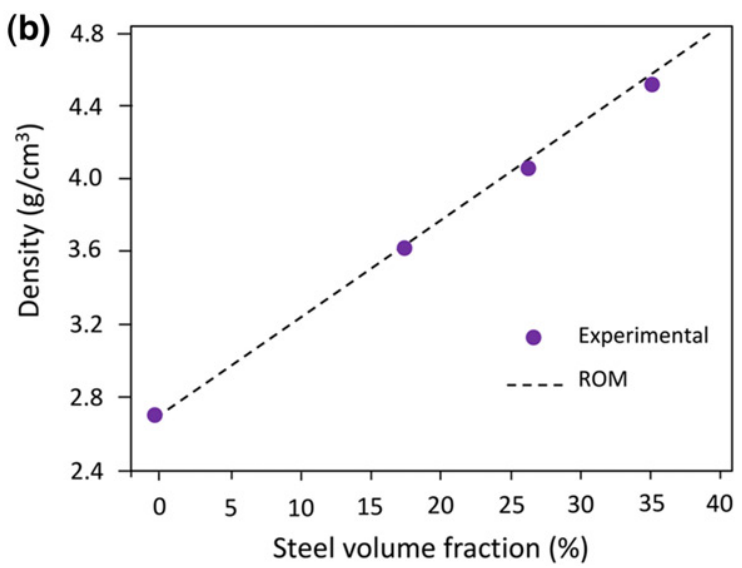

Figure (a) Young's modulus and
continuous wires of stainless steel. ${ }^{36,41}$ 

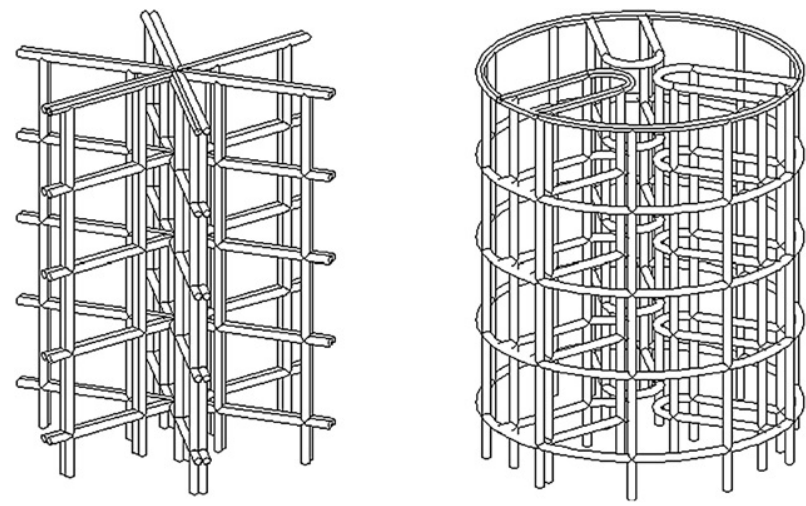

Figure 9. Schematic diagram of two different reinforcement preforms employed in $\mathrm{Al} /$ galvanized iron bimetallic materials. ${ }^{43}$

Table 1. Mechanical properties of aluminum reinforced with galvanized iron. ${ }^{44}$

\begin{tabular}{lcccccc}
\hline & $\begin{array}{c}\text { Young's } \\
\text { modulus } \\
\text { Materials }\end{array}$ & $\begin{array}{c}\text { Yield } \\
\text { strength } \\
(\mathrm{GPa})\end{array}$ & $\begin{array}{c}\text { Ultimate } \\
\text { tensile } \\
\text { strength } \\
(\mathrm{MPa})\end{array}$ & $\begin{array}{c}\text { Ductility } \\
(\%)\end{array}$ & $\begin{array}{c}\text { Density } \\
\left(\mathrm{g} / \mathrm{cm}^{3}\right)\end{array}$ & $\begin{array}{c}\text { Specific } \\
\text { stiffness } \\
\mathrm{GPa} / \\
\left(\mathrm{g} / \mathrm{cm}^{3}\right)\end{array}$ \\
\hline $\mathrm{Al}$ (matrix) & $70 \pm 2$ & $101 \pm 6$ & $120 \pm 3$ & $17 \pm 9$ & 2.7 & 25.9 \\
$\mathrm{Al} / 3$ vol.\%Fe* & $76 \pm 2$ & $108 \pm 2$ & $131 \pm 4$ & $5 \pm 3$ & 2.92 & 26.1 \\
$\mathrm{Al} / 3$ vol.\%Fe* & $81 \pm 2$ & $152 \pm 4$ & $186 \pm 15$ & $5 \pm 4$ & 2.81 & 28.8 \\
$\mathrm{Al} / 3$ vol.\%Fe* & $81 \pm 2$ & $150 \pm 6$ & $173 \pm 16$ & $3 \pm 2$ & 2.80 & 28.9 \\
$\mathrm{Al} / 5$ vol.\%Fe & $88 \pm 1$ & $105 \pm 5$ & $130 \pm 6$ & $7 \pm 3$ & 2.91 & 30.3 \\
\hline
\end{tabular}

*With different wire arrangement.

reinforcement phase. The presence of reinforcement results in the $7.6 \%$ reduction in the coefficient of thermal expansion, the $10 \%$ increase in the Young's modulus, the $20 \%$ increase in the $0.2 \%$ yield strength, and the $27 \%$ increase in the ultimate tensile strength.

As the critical characteristics in manufacturing the bimetallic materials, the interface between steel/iron and aluminum has been extensively studied through different approaches due to the avoidance of formation of detrimental phases. ${ }^{46}$ The interfaces between steel/iron and aluminum melt can be obtained by immersing the steel/iron into aluminum melt or overcasting aluminum melt onto the steel/iron surface. Dezellus et al. ${ }^{47}$ studied the formation of the interface layer, by immersing mild steel into Al-Si alloy melts, and the mechanical properties of interface, by the pushout test. The results showed that the $\mathrm{Al}_{5} \mathrm{Fe}_{2} \mathrm{Si}$ and $\mathrm{Al}_{9} \mathrm{Fe}_{2} \mathrm{Si}_{2}$ phases are formed at the interface and the crack initiation would occur in the intermetallic reaction layer. The formation of the intermetallic layer increases the mechanical properties of the bimetallic materials.

Viala et al. ${ }^{43}$ and Manasijevic et al..$^{45}$ prepared iron base insert reinforced $\mathrm{Al}-\mathrm{Si}$ alloys by gravity casting and revealed that a continuous metallurgical bond at the iron insert/Al-Si alloy interface can be achieved via the formation of $\mathrm{FeAl}_{3}$ and $\mathrm{Fe}_{2} \mathrm{Al}_{5}$ intermetallic phases on the interface. Bouayad et al. ${ }^{48}$ found that several intermetallic compounds, including $\gamma-\mathrm{Al}_{3} \mathrm{FeSi}$, $\eta-\mathrm{Al}_{5} \mathrm{Fe}_{2}(\mathrm{Si})$, and $\beta$ - $\mathrm{Al}_{5} \mathrm{FeSi}$, can be formed at the interface. The types of reaction products depend on the times and temperatures. Kobayashi and Yakou ${ }^{49}$ reported that the common sequence to form the reaction layer is $\mathrm{Fe} / \mathrm{Fe}_{2} \mathrm{Al}_{5} / \mathrm{FeAl}_{3} / \mathrm{Al}$, but Zhang et al. ${ }^{50}$ showed that the sequence of the reaction layer is $\mathrm{Fe} /$ $\eta-\mathrm{Al}_{5} \mathrm{Fe}_{2}(\mathrm{Si}) / \beta-\mathrm{Al}_{5} \mathrm{FeSi} / \mathrm{Al}-\mathrm{Si}$. The experimental results have confirmed that the surface modification of aluminizing can promote the formation of sound surface and metallurgical bonding between steel and $\mathrm{Al}$, which can be achieved by compound casting. Arghavani et al. $^{51}$ found that the $\mathrm{Zn}$ coating on the steel surface could enhance the wettability of bonding surface between steel and A5052 Al alloy. Liu et $\mathrm{al}^{52,53}$ found that the intermetallic compounds $\mathrm{Al}_{5} \mathrm{Fe}_{2} \mathrm{Zn}_{\mathrm{x}}$ and $\mathrm{Al}_{3} \mathrm{FeZn}_{\mathrm{x}}$ are formed at the interface between hot-dip galvanized steel and pure $\mathrm{Al}$ after compound casting. Generally, the zincate must be at an appropriate thickness for the reaction during overcasting. If the thickness is more than the diffusion distance, the $\mathrm{Zn}$ layer will still exist in the final microstructure after casting, which is detrimental to the mechanical properties. This has been partially confirmed by Schwankl et al. ${ }^{54}$ showing that the interface strength determined by zinc is the weakest part of the compound castings. If the coating is too thin, there are no sufficient compounds to provide bonding strength. Therefore, the bonding interface between the iron/steel and the aluminum alloy is the determining factor for manufacturing the bimetallic materials.

\subsection{Other Bimetallic Materials}

The Young's modulus of Al-based bimetallic materials reinforced by other metals can be roughly estimated by the ROM model and the results are shown in Figure 10. Comparing with the Young's modulus of $\mathrm{Fe}$ and $\mathrm{Ni}$ at a level of $\sim 200 \mathrm{GPa}$, the other continuous reinforcement - such as W and Mo - has a higher potential for the improvement of stiffness. However, the cost and processing procedure will remain an issue in its application.

\section{Stiffness improvement in aluminum- based composites}

Aluminum matrix composites reinforced with particles, short fibers/whiskers, or continuous fibers have received considerable attention over the past decades due to the attractive properties resulting from the 
combination of their constituents. ${ }^{55-57} \mathrm{Al} / \mathrm{TiB}_{2}, \mathrm{Al} /$ $\mathrm{TiC}, \mathrm{Al} / \mathrm{ZrB}{ }_{2}, \mathrm{Al} / \mathrm{SiC}, \mathrm{Al} / \mathrm{AlN}, \mathrm{Al} / \mathrm{Al}_{2} \mathrm{O}_{3}$, and $\mathrm{Al} / \mathrm{Mg}_{2} \mathrm{Si}$ have been reported to be able to improve the Young's modulus of cast $\mathrm{Al}$ alloys. ${ }^{58-60}$ The improvement of Young's modulus in AMCs can be successfully achieved through a variety of casting processes, including gravity casting, stirring casting, investment casting, die casting, vacuum-assisted casting, semisolid casting, and squeeze casting for manufacturing shaped components, or making billets by direct chill casting for further processing such as forging, extrusion or rolling.

The Young's modulus of pure aluminum can be enhanced from 70 to $240 \mathrm{GPa}$ by the reinforcement of 60 vol.\% continuous fiber. $\left[{ }^{19}\right]$ Similarly, the castings of $\mathrm{Al}-9 \mathrm{Si} / 20$ vol.\% $\mathrm{SiC}_{\mathrm{p}}$ composites significantly improve the Young's modulus with the wear resistance equivalent or better than that of gray cast irons. ${ }^{61}$ Discontinuously reinforced AMCs have been demonstrated to offer essentially isotropic properties

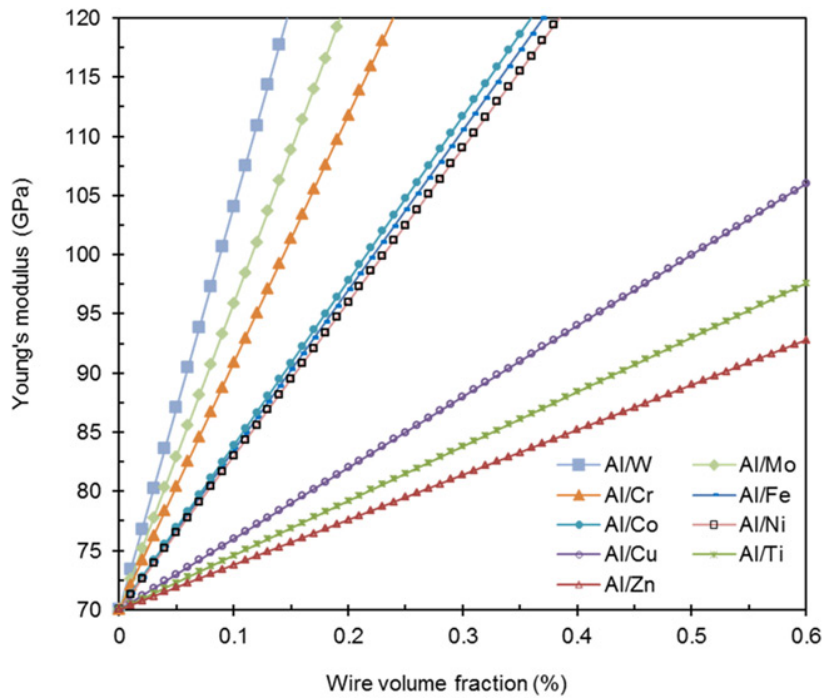

Figure 10. Young's modulus of aluminum-based bimetallic materials reinforced with different types of metallic wires estimated by rule of mixtures. with substantial improvements in stiffness and strength. However, a 50\% increase in the Young's modulus of $\mathrm{Al}$ alloys can be achieved by substituting a discontinuous reinforcement with continuous ones in AMCs. ${ }^{62}$ It is therefore capable of incorporating appropriate reinforcement in suitable volume fractions for casting aluminum components with improved Young's modulus and other technological properties such as high thermal conductivity, high specific strength, tailorable coefficient of thermal expansion, improved strength, and low density, which is dependent upon the composition, grain size, microstructure, and fabrication process.

The stiffness property of some reinforcement phases is listed in Table 2. These phases show the much-increased Young's modulus and melting point in comparison with pure aluminum. In AMCs, the reinforcement phase can be formed by in-situ reaction or by ex-situ additions. In the specific condition, the in-situ particles can act as nucleating sites for grain refinement or as strengthening phases to hinder dislocation motion. ${ }^{65,66}$ Currently, several fabrication methods including liquid state processing, deposition process, and solid-state processing have been developed for the manufacture of AMCs. Figure 11 shows the detailed casting process routes for manufacturing AMCs, which include infiltration techniques, ${ }^{67,68}$ stirring techniques, ${ }^{69,70}$ and rapid solidification. ${ }^{71,72}$ Liquid state processing is usually involved with the casting process, which is energy-efficient and costeffective for massive production. Products of complex shape can be formed directly through the melt mixture with reinforcement. It is very attractive to produce as-cast components of AMCs with a uniform reinforcement distribution of individual particles and structural integrity. However, during solidification, the particles ahead of the interface may get pushed, engulfed, or entrapped in the moving solidification front. The other difficulties in the casting process are the non-wettability of ex-situ particles by liquid metal,

Table 2. Properties of typical reinforcements. ${ }^{63-64}$

\begin{tabular}{|c|c|c|c|c|c|c|}
\hline Reinforcement & $\begin{array}{c}\text { Melting } \\
\text { point }\left({ }^{\circ} \mathrm{C}\right)\end{array}$ & $\begin{array}{c}\text { Young's } \\
\text { modulus (GPa) }\end{array}$ & UTS (MPa) & Density $\left(\mathrm{g} / \mathrm{cm}^{3}\right)$ & $\begin{array}{c}\text { Thermal conductivity } \\
(\mathrm{W} / \mathrm{m} \cdot \mathrm{K})\end{array}$ & $\begin{array}{l}\text { Coff. of thermal } \\
\text { expansion }\left(10^{-6} / \mathrm{K}\right)\end{array}$ \\
\hline $\mathrm{ZrB}_{2}$ & 3246 & 350 & & 6.09 & 140 & 7.4 \\
\hline AIN & 2200 & 330 & 2,100 & 3.26 & 150 & 3.3 \\
\hline $\mathrm{Al}_{2} \mathrm{O}_{3}$ & 2043 & 380 & 2,070 & 3.15 & 30 & 7.0 \\
\hline $\mathrm{TiC}$ & 3067 & 400 & 1,540 & 4.90 & 110 & 9.0 \\
\hline $\mathrm{TiB}_{2}$ & 3225 & 560 & 3,300 & 4.52 & 24 & 8.0 \\
\hline $\mathrm{Mg}_{2} \mathrm{Si}$ & 1102 & 120 & & 4.50 & 4.4 & 7.5 \\
\hline $\mathrm{ZrO}_{2}$ & 2715 & 350 & 2,070 & 4.84 & 3.3 & 7.0 \\
\hline $\mathrm{B}_{4} \mathrm{C}$ & 2763 & 425 & 2,690 & 2.35 & 39 & 3.5 \\
\hline $\mathrm{SiC}$ & 2730 & 450 & 2,280 & 3.21 & 120 & 3.4 \\
\hline VC & 2810 & 430 & & 5.77 & & 4.1 \\
\hline WC & 2870 & 640 & 500 & 15.52 & 60 & 5.1 \\
\hline $\mathrm{Si}_{3} \mathrm{~N}_{4}$ & 1900 & 207 & 530 & 3.18 & 28 & 1.5 \\
\hline
\end{tabular}




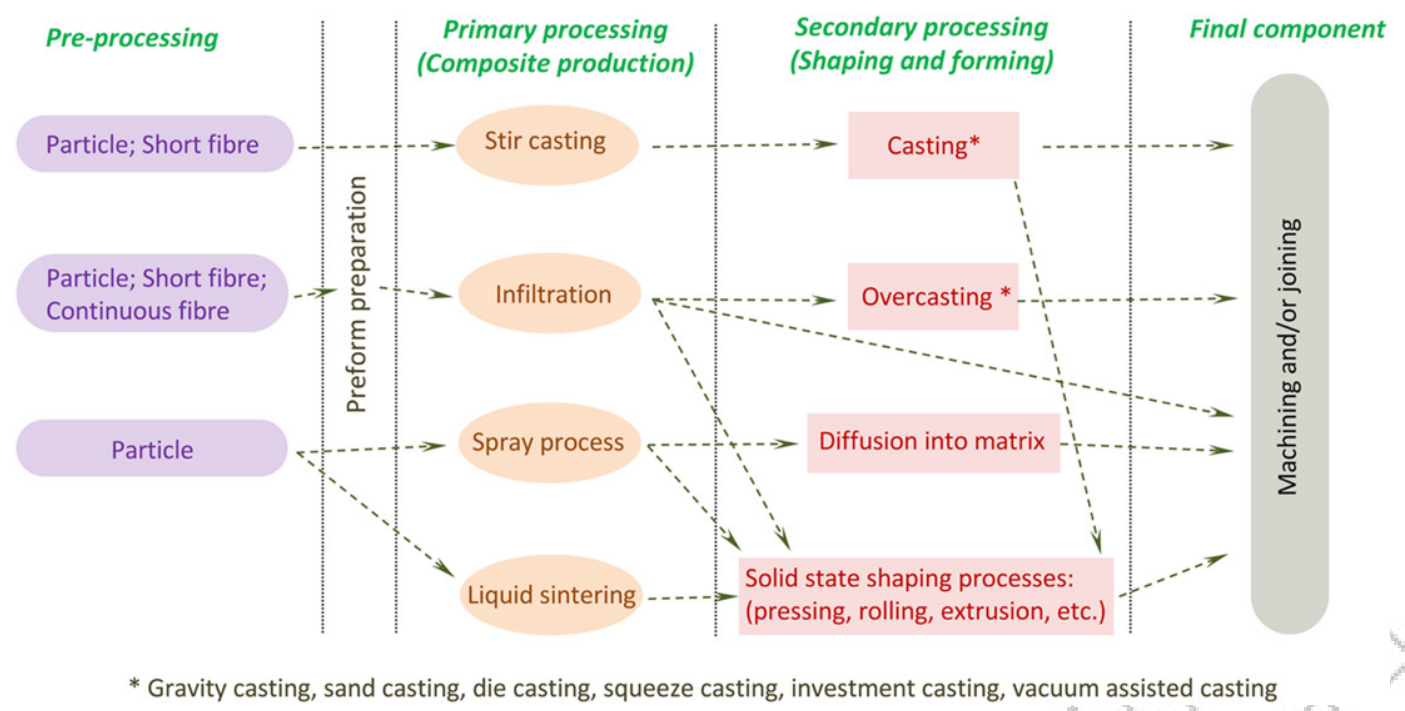

Figure 11. Schematic diagram of processing methods of AMCs.

and the particle-Al interface interaction. Although the addition of $\mathrm{Ni}, \mathrm{Mg}, \mathrm{Li}, \mathrm{Si}$, and $\mathrm{Ca}$ into $\mathrm{Al}$ melt can improve wettability either by changing the interfacial energy through some interfacial reaction or by modifying the oxide layer on the metal surface, ${ }^{73-75}$ the difficulty to obtain uniform dispersion of reinforcement particles is still an issue that hinders the adoption of AMCs in industry. ${ }^{76,77}$

In order to effectively improve the Young's modulus of AMCs, the generation of high modulus phases, the reinforcement phases with covalent/and ionic interatomic bonds in aluminum alloys are preferred approaches according to the nature of stiffness. ${ }^{78,79}$ Therefore, the in-situ method is better than the ex-situ method because the wettability between the in-situ formed phases and the aluminum matrix is significantly higher and is capable of forming clean and strong interfacial bonding in between. ${ }^{80,81}$ However, the in-situ method is suitable for particulate-reinforced AMCs because the in-situ techniques are not capable of making continuous fiber-reinforced AMCs.

The Young's modulus of composite materials can be estimated by theoretical modeling, which depends on the morphological arrangement of materials components. The most frequently used mathematical models include: (a) the rule of mixtures (ROM) and the inverse rule of mixtures (IROM), ${ }^{82}$ (b) the Halpin-Tsai model, ${ }^{83}$ (c) the Hashin-Shtrikman model, ${ }^{84}$ and (d) the Tuchinskii model. ${ }^{85}$ The ROM (upper bound) and IROM (lower bound) can be obtained according to the equal strain assumption and the equal stress assumption, respectively. ${ }^{16}$ The elastic properties of all of the composites are usually located between the ROM upper and IROM lower bounds. ${ }^{86}$ The Halpin-Tsai model has a more complicated mathematical structure than that of the ROM or IROM. In this model, the modulus of elasticity and the volume fraction of the components and the aspect ratio (ratio of the geometric dimensions) of the reinforcement are taken into account. It has been widely reported that Halpin-Tsai model is more accurate for particulate metal matrix composites. In the Hashin and Shtrikman (H-S) theorem, ${ }^{86}$ the upper bound rigorously corresponds to the composites containing the 'soft' inclusion matrix phase encapsulated by a 'stiffer' reinforcement phase, while the lower bound corresponds to the composites with a 'stiffer' inclusion reinforcement phase encapsulated by a 'softer' matrix phase. The H-S bounds are tighter than the ROM bounds and have been regarded as the best possible bounds on properties for isotropic two-phase composites. The Tuchinskii model ${ }^{87}$ considers a twophase interpenetrating skeletal structure. The calculated value of modulus can be a good estimation of experimental guidance. However, this review will not focus the modeling approaches and principles. Some existing results from modeling are used to review the experimental data.

\section{1. $A I / T i B_{2}$ Composites}

$\mathrm{TiB}_{2}$ is one of the most popular reinforcements for high modulus AMCs because of its Young's modulus of $560 \mathrm{GPa}$ and its easy synthesis using an in-situ process. ${ }^{87}$ The in-situ formed $\mathrm{TiB}_{2}$ offers a better interface with the aluminum matrix than the ex-situ added particles. ${ }^{88,89}$ The in-situ $\mathrm{Al} / \mathrm{TiB}_{2}$ composites can be synthesized using $\mathrm{K}_{2} \mathrm{TiF}_{6}$ and $\mathrm{KBF}_{4}$ salt reactions in molten $\mathrm{Al} ;{ }^{90}$ through a self-propagating high-temperature synthesis (SHS) reaction via Al-Ti-B powder
917

918

919

920

921

922

923

924

925

926

927

928

929

930

931

932

933

934

935

936

937

938

939

940

941

942

943

944

945

946

947

948

949

950

951

952 

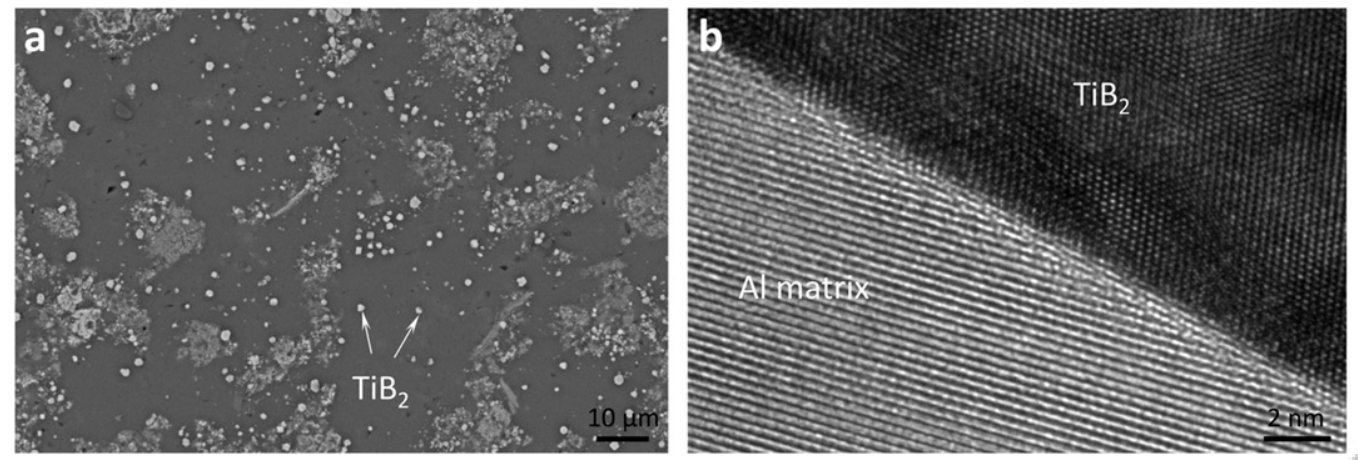

Figure 12. (a) A SEM micrograph of the Al-9Si-1Mg-0.7Cu/TiB $B_{2}$ composite with $14 \mathrm{wt} . \%$ TiB 2 particles and (b) a TEM micrograph showing the clean and well-bonded interface between the $\alpha-\mathrm{Al}$ and $\mathrm{TiB}_{2}$ particles. ${ }^{102}$

compact/preform added to molten $\mathrm{Al}^{91-93}$ through the reaction of $\mathrm{TiO}_{2}-\mathrm{H}_{3} \mathrm{BO}_{3}-\mathrm{Na}_{3} \mathrm{AlF}_{6}$ with $\mathrm{Al}^{9}{ }^{94}$ or via chemical reactions among $\mathrm{Al}, \mathrm{TiO}_{2}$, and $\mathrm{B}_{2} \mathrm{O}_{3}$ particles. ${ }^{95}$ It is generally believed that the presence of a $\mathrm{Al}_{3} \mathrm{Ti}$ phase in $\mathrm{Al} / \mathrm{TiB}_{2}$ composites is beneficial for grain refinement but is detrimental to the mechanical properties. ${ }^{96}$ The $\mathrm{Al}_{3} \mathrm{Ti}$ can be eliminated during synthesis by the proper control of temperature, time, and ratios of the raw materials. ${ }^{91,97}$ The presence of $\mathrm{Si}$ in cast $\mathrm{Al}$ alloys can improve the dispersion of $\mathrm{TiB}_{2}$ particles, ${ }^{98}$ although the $\mathrm{TiB}_{2}$ particles are still partially segregated in the eutectic regions because of the pushing mechanism during solidification. ${ }^{99-101}$ The typical microstructure of $\mathrm{Al} / \mathrm{TiB}_{2}$ composites is shown in Figure 12. The $\mathrm{Al}-9 \mathrm{Si}-1 \mathrm{Mg}-0.7 \mathrm{Cu} / \mathrm{TiB}_{2}$ composite can be produced with clean, smooth, and well-bonded interfaces between the aluminum matrix and $\mathrm{TiB}_{2}$ particles between 25 and 3,000 nm. ${ }^{103}$

The $\mathrm{TiB}_{2}$-reinforced AMCs can remarkably improve the mechanical properties, in particular the stiffness. The typical Young's modulus and other mechanical properties of particulate-reinforced $\mathrm{Al} /$ $\mathrm{TiB}_{2}$ composites are summarized in Table 3. The increase of the Young's modulus of $\mathrm{Al} / \mathrm{TiB}_{2}$ composites can be up to $40 \%$ higher than that of pure aluminum. ${ }^{106,107}$ The strength at elevated temperatures and the wear and fatigue resistance can also have a significant increase. ${ }^{108}$ Kumar et al. ${ }^{102}$ reported an increase of $108 \%$ in hardness, $123 \%$ in yield strength, $43 \%$ in UTS, and 33\% in Young's modulus of the Al-7Si cast alloy with $10 \mathrm{wt} . \%$ of $\mathrm{TiB}_{2}$, which provides a Young's modulus greater than $90 \mathrm{GPa}$. Han et al. ${ }^{108}$ studied the tensile properties of the Al-12Si alloy with $4 \mathrm{wt} . \%$ $\mathrm{TiB}_{2}$ particles and found that the improvement of the Young's modulus can be observed in the temperature range of $25-350{ }^{\circ} \mathrm{C}$. Amirkhanlou et al. ${ }^{102}$ reported that $\mathrm{Al}-9 \mathrm{Si}-1 \mathrm{Mg}-0.7 \mathrm{Cu} / 9$ vol.\% $\mathrm{TiB}_{2}$ can provide a Young's modulus greater than $94 \mathrm{GPa}$ and the yield strength up to $235 \mathrm{MPa}$ by the formation of $\alpha-\mathrm{Al}(\mathrm{Cu}$,
$\mathrm{Mg}$ ), $\mathrm{Si}$, and $\mathrm{TiB}_{2}$ phases in the microstructure. $\mathrm{Lu}$ et al. ${ }^{95}$ investigated the $\mathrm{Al} / \mathrm{TiB}_{2}$ composite and found that the Young's modulus reaches $107 \mathrm{GPa}$ by adding $15 \% \mathrm{TiB}_{2}$ into the $\mathrm{Al}$ matrix. Obviously, the main reason for high stiffness properties is formation of high volume fraction $\mathrm{TiB}_{2}$ with $565 \mathrm{GPa}$ modulus.

\subsection{Al/TiC composites}

Titanium carbide (TiC) is a hard refractory ceramic material with FCC crystal structures. The Young's modulus is approximately $400 \mathrm{GPa}$ and the shear modulus is $188 \mathrm{GPa}$ for the $\mathrm{TiC},{ }^{109,110}$ which is a good candidate as reinforcement for improving stiffness of aluminum alloys ${ }^{111,112}$. Al/TiC in-situ composites can be synthesized by several techniques, including: (a) the reaction of $\mathrm{K}_{2} \mathrm{TiF}_{6}$ salt and graphite, (b) the direct reaction of $\mathrm{Ti}$ and $\mathrm{C}$ powders, (c) the addition of $\mathrm{Al}-\mathrm{Ti}-\mathrm{C}$ powder into the $\mathrm{Al}$ melt, and (d) the reaction of $\mathrm{CH}_{4}$ gas with the Al-Ti melt. The reactions can be at a level of $1000^{\circ} \mathrm{C}$ for 30 minutes for Al-4.5 Cu alloys. ${ }^{113,114}$ The in-situ formed TiC particles can be smaller than $1 \mu \mathrm{m}$ in size or in a range of several micrometers. ${ }^{15,116}$ The formation of other phases, such as $\mathrm{Al}_{4} \mathrm{C}_{3}$ and $\mathrm{Al}_{3} \mathrm{Ti}$ phases, is considered to be unfavorable in $\mathrm{Al} / \mathrm{TiC}$ composites. ${ }^{116,117}$

On top of the enhancement of mechanical properties, the addition of $\mathrm{TiC}$ particles into aluminum melt has a dramatic improvement on the Young's modulus, as shown in Figure 13. Samer et al. ${ }^{118}$ obtained the Young's modulus of $106 \mathrm{GPa}$, the yield strength of $450 \mathrm{MPa}$, and the elongation of $6 \%$ in the composites containing 22 vol.\% TiC in pure Al. Mohapatra et al. $^{119}$ confirmed that the Young's modulus is increased from $70 \mathrm{GPa}$ of pure aluminum to $88.78 \mathrm{GPa}$ after adding 20 vol.\% TiC. The mechanical properties of $\mathrm{Al}-4.5 \% \mathrm{Cu}$ alloy reinforced with different amounts of $\mathrm{TiC}$ are summarized in Table 4, in which the addition of $10 \mathrm{wt} . \% \mathrm{TiC}$ increases the
1007

1008

1009

1010

1011

1012

1013

1014

1015

1016

1017

1018

1019

1020

1021

1022

1023

1024

1025

1026

1027

1028

1029

1030

1031

1032

1033

1034

1035

1036

1037

1038

1039

1040

1041

1042

1043

1044

1045

1046

1047

1048

1049

1050

1051

1052

1053

1054

1055

1056

1057

1058 
Table 3. Mechanical properties of $\mathrm{Al} / \mathrm{TiB}_{2}$ cast composites synthesized by $\mathrm{K}_{2} \mathrm{TiF}_{6}$ and $\mathrm{KBF}_{4}$ salt reaction. ${ }^{104,105}$

\begin{tabular}{|c|c|c|c|c|c|}
\hline Materials & Temperature $\left({ }^{\circ} \mathrm{C}\right)$ & Young's modulus (GPa) & $0.2 \%$ Proof stress (MPa) & UTS (MPa) & Elongation (\%) \\
\hline $\mathrm{Al}-7 \mathrm{Si} / 5$ vol. $\% \mathrm{TiB}_{2}$ & 25 & 83.0 & 126 & 175 & 7.00 \\
\hline $\mathrm{Al}-7 \mathrm{Si} / 10$ vol. $\% \mathrm{TiB}_{2}$ & 25 & 92.0 & 152 & 209 & 4.60 \\
\hline Al-12Si/4 wt. $\% \mathrm{TiB}_{2}$ & 25 & 85.0 & 240 & 298 & 1.50 \\
\hline Al-12Si/4 wt. $\% \mathrm{TiB}_{2}$ & 200 & 80.0 & 189 & 233 & 3.00 \\
\hline Al-12Si/4 wt. $\% \mathrm{TiB}_{2}$ & 350 & 66.0 & 84 & 96 & 5.80 \\
\hline $\mathrm{A} 356 / 2.1$ vol. $\% \mathrm{TiB}_{2}$ & 25 & 72.9 & 209 & 235 & 7.81 \\
\hline A356/4.7 vol. $\% \mathrm{TiB}_{2}$ & 25 & 76.3 & 212 & 252 & 7.36 \\
\hline $\mathrm{A} 356 / 8.4$ vol. $\% \mathrm{TiB}_{2}$ & 25 & 82.2 & 217 & 258 & 2.73 \\
\hline A356/2.1 vol. $\% \mathrm{TiB}_{2}$ & 25 & 78.1 & 305 & 375 & 4.88 \\
\hline $\mathrm{A} 356 / 4.7$ vol. $\% \mathrm{TiB}_{2}$ & 25 & 80.2 & 317 & 377 & 1.90 \\
\hline A356/8.4 vol. $\% \mathrm{TiB}_{2}$ & 25 & 84.1 & 347 & 391 & 1.32 \\
\hline $\mathrm{Al} / 5$ vol. $\% \mathrm{TiB}_{2}$ & 25 & 69.0 & 188 & 284 & 3.50 \\
\hline $\mathrm{Al} / 10$ vol. $\% \mathrm{TiB}_{2}$ & 25 & 84.0 & 249 & 326 & 1.92 \\
\hline $\mathrm{Al} / 5$ vol. $\% \mathrm{TiB}_{2}$ & 25 & 82.0 & 96 & 124 & 9.20 \\
\hline $\mathrm{Al} / 10$ vol. $\% \mathrm{TiB}_{2}$ & 25 & 87.0 & 128 & 164 & 6.30 \\
\hline $\mathrm{Al} / 15$ vol. $\% \mathrm{TiB}_{2}$ & 25 & 91.0 & 124 & 153 & 5.50 \\
\hline $\mathrm{Al}-\mathrm{Cu} / 10$ vol. $\% \mathrm{TiB}_{2}$ & 25 & 77.0 & 153 & 230 & 5.50 \\
\hline $\mathrm{Al}-\mathrm{Cu} / 10$ vol. $\% \mathrm{TiB}_{2}$ & 25 & 83.0 & 311 & 361 & 1.30 \\
\hline $\mathrm{Al} / 15$ vol. $\% \mathrm{TiB}_{2}$ & 25 & 107.0 & 274 & 389 & 1.99 \\
\hline $\mathrm{Al} / 15$ vol. $\% \mathrm{TiB}_{2}$ & 25 & 91.0 & 171 & 223 & 4.60 \\
\hline $\mathrm{Al}-\mathrm{Cu} / 15$ vol. $\% \mathrm{TiB}_{2}$ & 25 & 93.0 & 248 & 333 & 2.30 \\
\hline
\end{tabular}

Young's modulus to $99 \mathrm{GPa}^{121}$ In addition, the Young's modulus of the $\mathrm{Al} / \mathrm{TiC}$ composite is close to the upper limit calculated from the Hashin-Shtrikman model, ${ }^{122,123}$ suggesting that the in-situ synthesis of TiC particles leads to strong interfacial bonding and the attendant load transfer. Despite the high stiffness of $\mathrm{Al} / \mathrm{TiC}$ in-situ composites, the porosity level and other oxide impurities in the melt are the main concerns because of the high synthesis temperature of $1000-1200^{\circ} \mathrm{C}$. High temperature processing also results in limitations for the industrial applications of in-situ $\mathrm{Al} / \mathrm{TiC}$ composites.

\subsection{Al/SiC Composites}

$\mathrm{SiC}$ reinforcements are usually added into $\mathrm{Al}$ melt through ex-situ additions incorporating with stirring or mixing. ${ }^{124,125}$ Casting routes can be gravity casting and squeeze casting. Alternatively, the alloy is infiltrated into a porous preform formed by $\mathrm{SiC}$ reinforcements. The wettability between the $\mathrm{SiC}$ reinforcements and the aluminum alloy is a crucial concern in association with the optimum fluidity of the alloy. One of the main problems during the processing and casting of $\mathrm{Al} / \mathrm{SiC}$ composites is that liquid aluminum attacks $\mathrm{SiC}$ reinforcements through chemical reaction, forming $\mathrm{Al}_{4} \mathrm{C}_{3}$ and $\mathrm{Si}^{126,127}$ Particle clustering has greater effects on the flow behavior and mechanical properties of $\mathrm{Al} / \mathrm{SiC}$ AMCs because the particle clustering microstructure experiences a higher percentage of particle fracture than that with particle random distribution. ${ }^{127,128}$ The stirring casting is an effective way to promote the distribution of ex-situ particles. ${ }^{129,130}$

Table 5 summarizes the Young's modulus and mechanical properties of ex-situ Al/SiC AMCs. The

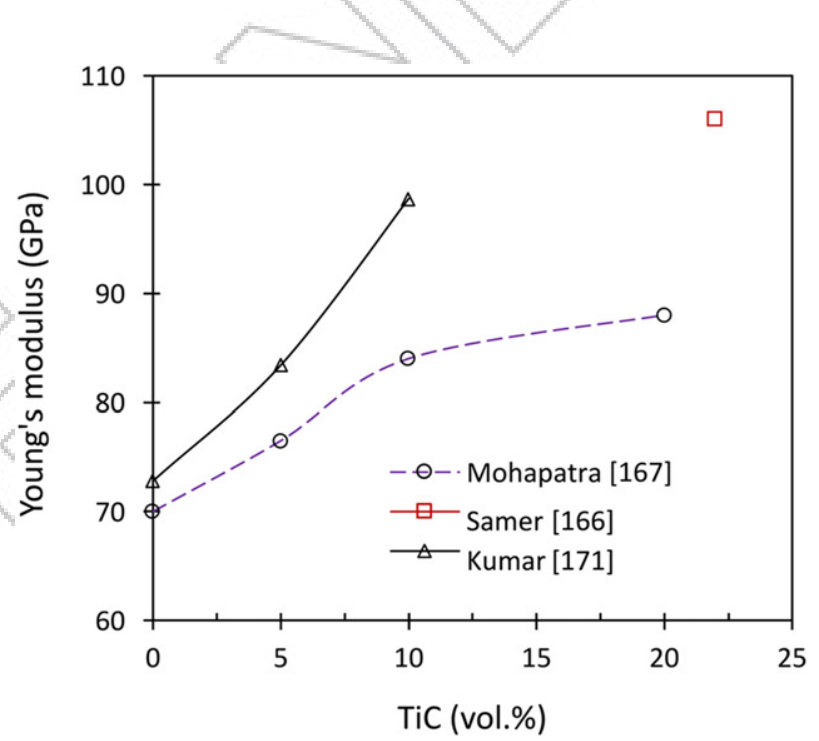

Figure 13. Effect of $\mathrm{TiC}$ on the Young's modulus of $\mathrm{Al} /$ TiC composites.

Young's modulus of the AMCs with cast aluminum alloys can be enhanced to $114 \mathrm{GPa}$ when the reinforcement is at a level of $20 \mathrm{vol} . \%$. The castability is a significant concern when the $\mathrm{SiC}$ addition is beyond this level. For wrought aluminum alloys, the addition of $\mathrm{SiC}$ reinforcement can be at a level of 25 vol.\% for ing. The Young's modulus can be $140 \mathrm{GPa}$, which is double the Young's modulus of pure aluminum.

\subsection{Al/AIN Composites}

Aluminum nitride (AlN) has a Young's modulus of $310 \mathrm{GPa}$ and therefore it can fairly increase the modulus of aluminum castings. ${ }^{132,133}$ However, because of casting and the subsequent plastic deformation process- 
Table 4. Mechanical properties of Al matrix and Al-4.5Cu/TiC in-situ composites. ${ }^{120}$

\begin{tabular}{lccc}
\hline Materials & Vickers hardness (HV5) & Young's modulus (GPa) & Yield strength (MPa) \\
\hline Al-4.5\%Cu & 55.19 & 72.8 & 81.5 \\
Al-4.5Cu/5wt.\% TiC & 61.12 & 83.4 & 95.7 \\
Al-4.5Cu/7wt.\% TiC & 69.43 & 91.8 & 118 \\
Al-4.5Cu/10wt.\% TiC & 75.76 & 98.7 & 134 \\
\hline
\end{tabular}

Table 5. Young's modulus and mechanical properties of ex-situ Al/SiC AMCs. ${ }^{67,131}$

\begin{tabular}{|c|c|c|c|c|c|c|}
\hline Materials & Reinforcement & Casting method & Young's modulus (GPa) & Yield strength (MPa) & UTS (MPa) & Elongation (\%) \\
\hline Al-10Si-3Cu-1Mg-1.25Ni & 10 vol. $\% \mathrm{SiC}$ & Gravity & 88 & 359 & 372 & 0.3 \\
\hline $\mathrm{Al}-10 \mathrm{Si}-3 \mathrm{Cu}-1 \mathrm{Mg}-1.25 \mathrm{Ni}$ & 20 vol. $\% \mathrm{SiC}$ & Gravity & 101 & 372 & 372 & 0.1 \\
\hline Al-9Si-0.5Mg & 10 vol. $\% \mathrm{SiC}$ & Gravity & 86 & 303 & 338 & 1.2 \\
\hline Al-9Si-0.5Mg & 20 vol. $\%$ SiC & Gravity & 99 & 338 & 359 & 0.4 \\
\hline Al-10Si-1Fe-0.6 Mn & 10 vol. $\% \mathrm{SiC}$ & Pressure die cast & 91 & 221 & 310 & 0.9 \\
\hline Al-10Si-1Fe-0.6 Mn & 20 vol. $\%$ SiC & Pressure die cast & 108 & 248 & 303 & 0.5 \\
\hline Al-10Si-3.25Cu-1Fe-0.6 Mn & 10 vol. $\% \mathrm{SiC}$ & Pressure die cast & 94 & 241 & 345 & 1.2 \\
\hline Al-3.25Cu-1Fe-0.6 Mn & 20 vol. $\%$ SiC & Pressure die cast & 114 & 303 & 352 & 0.4 \\
\hline A356 & 10 vol. $\% \mathrm{SiC}$ & Casting & 81 & 283 & 303 & 0.6 \\
\hline A356 & 15 vol. $\%$ SiC & Casting & 90 & 324 & 331 & 0.3 \\
\hline A356 & 20 vol. $\% \mathrm{SiC}$ & Casting & 97 & 331 & 352 & 0.4 \\
\hline $\mathrm{Al}-12 \mathrm{Si}-\mathrm{Ni}-\mathrm{Cu}$ & 20 vol. $\%$ SiC & Squeeze casting & 111 & 293 & 384 & \\
\hline Al-7Si-Mg-Fe & 15 vol. $\% \mathrm{SiC}$ & Gravity & 98 & 183 & 280 & 1.0 \\
\hline $\mathrm{Al}-3 \mathrm{Mg}$ & 20 vol. $\%$ SiC & Gravity & 105 & 377 & 408 & 1.4 \\
\hline $\mathrm{Al}-4.4 \mathrm{Cu}-\mathrm{Si}-\mathrm{Mg}$ & 15 vol. $\% \mathrm{SiC}$ & Gravity & 107 & 342 & 350 & 1.6 \\
\hline Al-7Si-0.3Mg & 10 vol. $\% \mathrm{SiC}$ & Casting & 82 & 287 & 308 & 0.6 \\
\hline Al-7Si-0.3Mg & 15 vol. $\%$ SiC & Casting & 91 & 329 & 336 & 0.3 \\
\hline Al-7Si-0.3Mg & 20 vol. $\%$ SiC & Casting & 98 & 336 & 357 & 0.4 \\
\hline A380 & 10 vol. $\% \mathrm{SiC}$ & Casting & 95 & 245 & 332 & 1.0 \\
\hline A380 & 20 vol. $\% \mathrm{SiC}$ & Casting & 114 & 308 & 356 & 0.4 \\
\hline AA6061 & 20 vol. $\%$ SiC & Casting-forming & 119 & 448 & 551 & 1.4 \\
\hline AA6061 & 20 vol. $\%$ SiC & Casting-extrusion & 108 & 414 & 545 & 2.0 \\
\hline AA6061 & 20 vol. $\% \mathrm{SiC}$ & Casting-hot rolling & 104 & 402 & 550 & 4.5 \\
\hline AA2014 & 15 vol. $\% \mathrm{SiC}$ & Casting-forming & 100 & 466 & 493 & 2.0 \\
\hline AA2024 & 20 vol. $\% \mathrm{SiC}$ & Casting-forming & 110 & 465 & 620 & 2.0 \\
\hline AA2024 & 25 vol. $\% \mathrm{SiC}$ & Casting-forming & 140 & 470 & 800 & 2.0 \\
\hline AA2024 & 15 vol. $\% \mathrm{SiC}$ & Casting-hot rolling & 96 & & 530 & 2.4 \\
\hline AA2024 & 15 vol. $\% \mathrm{SiC}$ & Casting-hot rolling & & & 330 & 1.2 \\
\hline AA2618 & 12 vol. $\% \mathrm{SiC}$ & Casting-forming & 98 & 460 & 532 & 3.0 \\
\hline AA2124 & 17.8 vol. $\% \mathrm{SiC}$ & Casting-forming & 100 & 400 & 610 & 6.0 \\
\hline AA2124 & 20 vol. $\% \mathrm{SiC}$ & Casting-forming & 105 & 405 & 560 & 7.0 \\
\hline AA2124 & 25 vol. $\% \mathrm{SiC}$ & Casting-forming & 116 & 490 & 630 & 3.0 \\
\hline AA7075 & 15 vol. $\% \mathrm{SiC}$ & Casting-forming & 95 & 556 & 601 & 3.0 \\
\hline AA7075 & 15 vol. $\% \mathrm{SiC}$ & Casting-forming & 90 & 598 & 643 & 2.0 \\
\hline AA7075 & 20 vol. $\% \mathrm{SiC}$ & Casting-forming & 105 & 665 & 735 & 2.0 \\
\hline AA8090 & 13 vol. $\% \mathrm{SiC}$ & Casting-forming & 101 & 455 & 520 & 4.0 \\
\hline AA8090 & 13 vol. $\% \mathrm{SiC}$ & Casting-forming & 101 & 499 & 547 & 3.0 \\
\hline AA8090 & 17 vol. $\%$ SiC & Casting-forming & 105 & 310 & 460 & 5.5 \\
\hline AA8090 & 17 vol. $\% \mathrm{SiC}$ & Casting-forming & 105 & 450 & 540 & 3.5 \\
\hline
\end{tabular}

the low thermal expansion and good thermal conductivity, $\mathrm{Al} / \mathrm{AlN}$ is attractive in some specific applications. In-situ Al/AlN composites are usually made by a direct reaction between $\mathrm{N}_{2}$ and/or $\mathrm{NH}_{3}$ gas with the molten aluminum alloys. ${ }^{134,135}$ The nitridation of $\mathrm{Al}$ is a thermodynamically exothermic process and is energetically favorable over an extensive temperature range. The formed AlN particles are smaller than 10 $\mu \mathrm{m}$ and show a hexagonal morphology. ${ }^{136,137}$ The AlN particles can be less than $2 \mu \mathrm{m}$ in the $\mathrm{Al} / \mathrm{AlN}$ composites synthesized by adding $\mathrm{NH}_{3}$ into the melt in the temperature range from 1,100 to $1,270{ }^{\circ} \mathrm{C} .{ }^{138} \mathrm{In}$ comparison with the purified $\mathrm{N}_{2}$ bubbling gas, $\mathrm{NH}_{3}$ can enhance the formation of the AlN phase in aluminum melt. ${ }^{137}$ Chedru ${ }^{139}$ studied ex-situ Al/AlN AMCs with squeeze casting and found that $\mathrm{Al} / \mathrm{AlN}$
Table 6. Young's modulus and shear modulus of reinforced and non-reinforced materials. ${ }^{138}$

\begin{tabular}{lcc}
\hline & Young's modulus (GPa) & Shear modulus (GPa) \\
\hline Al-4Cu-1Mg & 72.9 & 27.1 \\
Al-4Cu-1Mg/45\% AIN & 146.3 & 56.5 \\
Al-1Mg-0.5Si & 72.5 & 27.1 \\
Al-1Mg-0.5Si/42\% AIN & 141.3 & 54.6 \\
Al-3Mg & 71.3 & 26.6 \\
Al-3Mg/48\% AIN & 149.5 & 58.2 \\
\hline
\end{tabular}

composites can significantly improve the mechanical properties, as shown in Table 6. Balog ${ }^{139}$ studied Al/ AlN AMCs with cold isostatic pressing (CIP) and extrusion, and the results are shown in Figure 14. The Young's modulus is significantly increased when increasing the content of AlN in the AMCs. However, the studies for castable materials are still very limited 


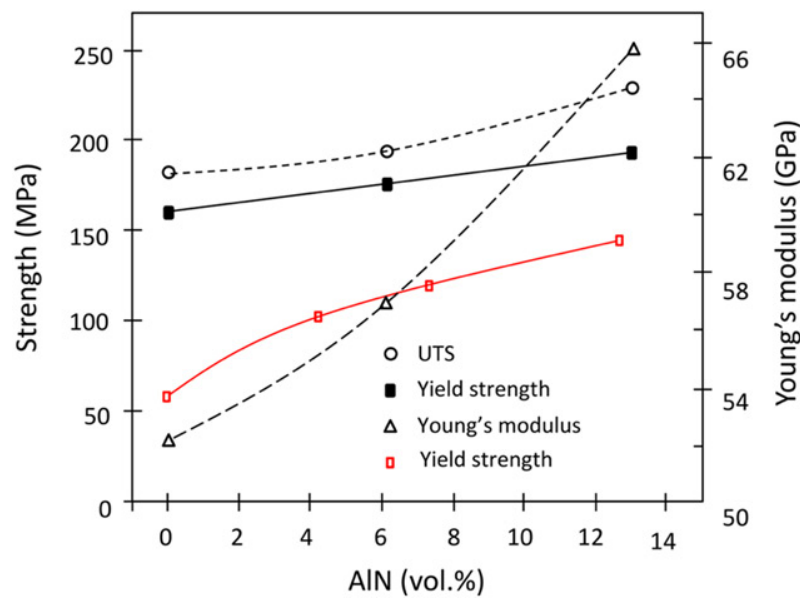

Figure 14. Ultimate tensile strength (UTS), yield strength, and Young's modulus of Al-AIN nanocomposites prepared by CIP with subsequent extrusion. ${ }^{140}$

due to high temperature manufacturing methods for in-situ $\mathrm{Al} / \mathrm{AlN}$ composites.

\section{5. $\mathrm{Al} / \mathrm{ZrB}{ }_{2}-\mathrm{Al}_{3} \mathrm{Zr}$ Composites}

$\mathrm{Al} / \mathrm{ZrB}_{2}-\mathrm{Al}_{3} \mathrm{Zr}$ composites use the hybrid reinforcement phases of $\mathrm{ZrB}_{2}$ and $\mathrm{Al}_{3} \mathrm{Zr}$. The Young's modulus is $350 \mathrm{GPa}$ for $\mathrm{ZrB}_{2}$ and $205 \mathrm{GPa}$ for $\mathrm{Al}_{3} \mathrm{Zr}$. $\mathrm{Al} / \mathrm{ZrB}_{2}$ $\mathrm{Al}_{3} \mathrm{Zr}$ in-situ composites are usually synthesized by the addition of $\mathrm{K}_{2} \mathrm{ZrF}_{6}$ and $\mathrm{KBF}_{4}$ salts to $\mathrm{Al}$ melt. ${ }^{141}$ Zhang et al. ${ }^{142}$ synthesized in-situ $\mathrm{ZrB}_{2}$ and $\mathrm{Al}_{3} \mathrm{Zr}$ particles in A356 alloy with $\mathrm{K}_{2} \mathrm{ZrF}_{6}$ and $\mathrm{KBF}_{4}$ salts. The $\mathrm{ZrB}_{2}$ and $\mathrm{Al}_{3} \mathrm{Zr}$ particles are from 0.3 to $0.5 \mu \mathrm{m}$, as shown in Figure 15. Zhao et al. ${ }^{144}$ reported that the morphologies of $\mathrm{Al}_{3} \mathrm{Zr}$ are sensitive to the temperature of the Al melt. When the temperatures change from 850 to $1000^{\circ} \mathrm{C}$, the morphologies of the $\mathrm{Al}_{3} \mathrm{Zr}$ particles can be spherical shape, tetragon shape, rod shape, and fiber shape, but the $\mathrm{ZrB}_{2}$ particles show no obvious diversity in morphology. The particulate-reinforced $\mathrm{Al} / \mathrm{ZrB}_{2}-\mathrm{TiB}_{2}$ composites can also be formed by the addition of $\mathrm{KBF}_{4}, \mathrm{~K}_{2} \mathrm{ZrF}_{6}$, and $\mathrm{K}_{2} \mathrm{TiF}_{6}$ salts into $\mathrm{Al}$ melt, ${ }^{145,146}$ by which the formed $\mathrm{TiB}_{2}$ and $\mathrm{ZrB}_{2}$ particles are hexagonal with the average size less than $2 \mu \mathrm{m} .{ }^{147}$

The $\mathrm{Al} / \mathrm{ZrB}_{2}-\mathrm{Al}_{3} \mathrm{Zr}$ composites show valuable improvement in stiffness, strength, and wear properties with the increase in $\mathrm{ZrB}_{2}$ contents. ${ }^{148,149}$ As shown in Figure 16, Selvam and Dinaharan ${ }^{150}$ verified the stiffness improvement of $7075 / \mathrm{ZrB}_{2}$ composite, which is further attributed to $\mathrm{ZrB}_{2}$ that has a covalent interatomic bond and high intrinsic modulus. However, Gautam et al. ${ }^{151,152}$ found that the improvement of the Young's modulus in $\mathrm{Al} / \mathrm{ZrB}_{2}-\mathrm{Al}_{3} \mathrm{Zr}$ hybrid composite is insignificant when the volume

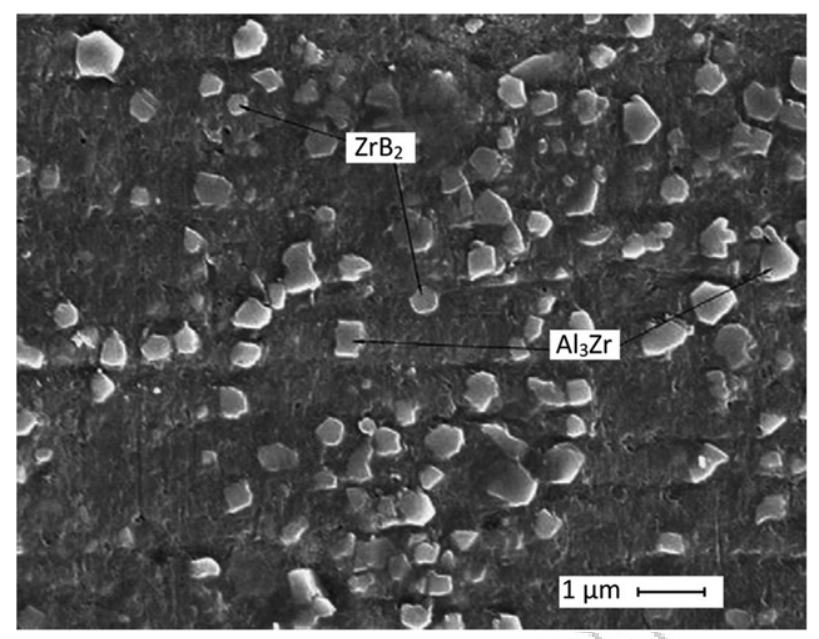

Figure 15. SEM image of the $A l / Z r B_{2}-A_{3} \mathrm{Zr}$ hybrid composite. ${ }^{143}$

fraction of $\mathrm{ZrB}_{2}$ particles increases. The main challenge for fabrication of high modulus in-situ composites by casting processes is volume fraction of reinforcement. In fact, it is difficult to form high volume fraction of particles through salt reaction or direct reaction between the gases with the molten aluminum alloys.

\subsection{Other Particulate-reinforced AMCs}

The other typical reinforcements listed in Table 2 are capable of being synthesized by in-situ reactions. However, the compounds with high modulus are more attractive. In addition to that described in the previous section, $\mathrm{Al}_{2} \mathrm{O}_{3}, \mathrm{WC}, \mathrm{B}_{4} \mathrm{C}$, and $\mathrm{VC}$ are also good candidates for improving the Young's modulus of aluminum composites. For example, the in-situ Al/ $\mathrm{Al}_{2} \mathrm{O}_{3}$ composites can be synthesized by: (a) the direct melt oxidation of aluminum alloys at high temperature, ${ }^{153}$ (b) directly passing oxygen into the aluminum melt to form $\mathrm{Al}_{2} \mathrm{O}_{3},{ }^{154}$ and (c) the displacement reactions between metal oxides and aluminum to produce $\mathrm{Al}_{2} \mathrm{O}_{3}$ particulate reinforcement. However, the experimental evidence for the improvement of Young's modulus in those in-situ AMCs is not sufficient.

The manufacture and the properties of ex-situ AMCs have been comprehensively reviewed by Rohatgi et al. ${ }^{31} \mathrm{Al} / \mathrm{SiC}$ and $\mathrm{Al} / \mathrm{TiB}_{2}$ have also been discussed in the present paper. The other ex-situ AMCs processed by casting methods are shown in Table 7. It is possible to combine up to $20 \mathrm{vol} . \%$ of $\mathrm{Al}_{2} \mathrm{O}_{3}$ into different aluminum alloys for improving the Young's modulus. The dominant factors in controlling the Young's modulus of ex-situ AMCs are the type, shape, volume fraction, and distribution of reinforcement 

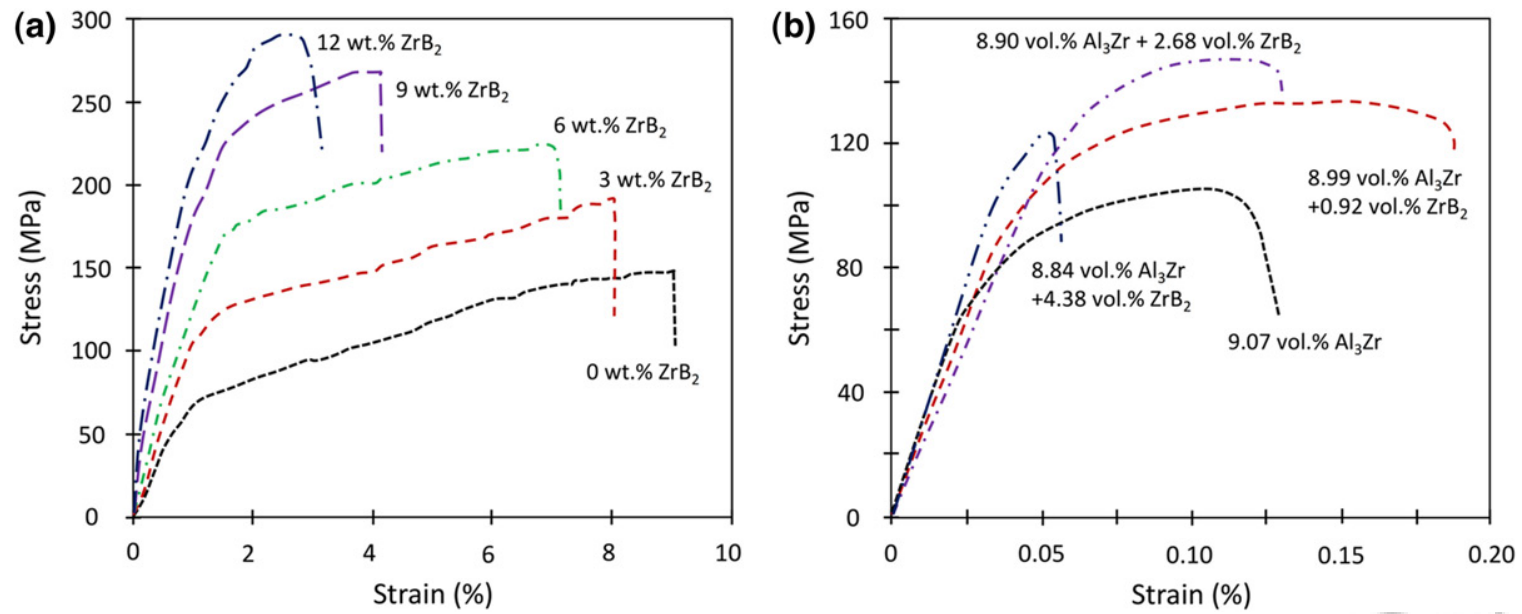

Figure 16. Stress-strain graphs showing: (a) the effect of $\mathrm{ZrB} B_{2}$ content in $A A 7075 / Z r B_{2}$ in-situ composites and (b) the effect of $\mathrm{ZrB}_{2}$ and $\mathrm{Al}_{3} \mathrm{Zr}$ content in $\mathrm{AA} 5052 / \mathrm{ZrB}_{2}-\mathrm{Al}_{3} \mathrm{Zr}$ in-situ composites. ${ }^{149}{ }^{150}$

Table 7. Young's modulus and mechanical properties of Al-based particulate ex-situ composites. ${ }^{19,66,130}$

\begin{tabular}{|c|c|c|c|c|c|c|}
\hline Materials & Reinforcement & Casting method & Young's modulus (GPa) & $\mathrm{YS}(\mathrm{MPa})$ & UTS (MPa) & Elongation (\%) \\
\hline $\mathrm{Al}-12 \mathrm{Si}-\mathrm{Ni}-\mathrm{Cu}$ & 20 vol. $\% \mathrm{Al}_{2} \mathrm{O}_{3}$ & Squeeze casting & 95 & 210 & 297 & \\
\hline $\mathrm{Al}-4.2 \mathrm{Cu}-1.4 \mathrm{Mg}-0.6 \mathrm{Ag}$ & 25 vol. $\% \mathrm{Al}_{2} \mathrm{O}_{3}$ & Stir casting-forming & 97 & & 460 & 0.5 \\
\hline $\mathrm{Al}-4 \mathrm{Cu}-1 \mathrm{Mg}-0.5 \mathrm{Ag}$ & 15 vol. $\% \mathrm{Al}_{2} \mathrm{O}_{3}$ & Stir casting-forming & 90 & & 510 & 1.3 \\
\hline A201 & 20 vol. $\% \mathrm{TiC}$ & Stir casting-forming & 105 & 420 & & 2.0 \\
\hline AA6061 & 10 vol. $\% \mathrm{Al}_{2} \mathrm{O}_{3}$ & Stir casting-forming & 81 & 297 & 338 & 7.6 \\
\hline AA6061 & 15 vol. $\% \mathrm{Al}_{2} \mathrm{O}_{3}$ & Stir casting-forming & 88 & 386 & 359 & 5.4 \\
\hline AA6061 & 20 vol. $\% \mathrm{Al}_{2} \mathrm{O}_{3}$ & Stir casting-forming & 99 & 359 & 379 & 2.1 \\
\hline AA6061 & 15 vol. $\% \mathrm{Al}_{2} \mathrm{O}_{3}$ & Casting-forming & 91 & 342 & 364 & 3.2 \\
\hline AA6061 & 15 vol. $\% \mathrm{Al}_{2} \mathrm{O}_{3}$ & Casting-forming & 98 & 405 & 460 & 7.0 \\
\hline AA6061 & 20 vol. $\% \mathrm{Al}_{2} \mathrm{O}_{3}$ & Casting-forming & 105 & 420 & 500 & 5.0 \\
\hline AA6061 & 25 vol. $\% \mathrm{Al}_{2} \mathrm{O}_{3}$ & Casting-forming & 115 & 430 & 515 & 4.0 \\
\hline AA2014 & 10 vol. $\% \mathrm{Al}_{2} \mathrm{O}_{3}$ & Stir casting-forming & 84 & 483 & 517 & 3.3 \\
\hline AA2014 & 15 vol. $\% \mathrm{Al}_{2} \mathrm{O}_{3}$ & Stir casting-forming & 92 & 476 & 503 & 2.3 \\
\hline AA2014 & 20 vol. $\% \mathrm{Al}_{2} \mathrm{O}_{3}$ & Stir casting-forming & 101 & 483 & 503 & 0.9 \\
\hline
\end{tabular}

phases. The porosity and other microstructural characteristics are also critical for property improvement. ${ }^{155,156}$ The presence of matrix-particle decohesion, particle cracking, and void growth can decrease the load transfer capability of the interface and, consequently, decrease the Young's modulus of the AMCs. The subsequent mechanical processes are an effective approach to enhance the quality of the interface between matrix and reinforcement in ex-situ cast composites as well as the distribution of high modulus particles, as shown in Table 7. Secondary plastic deformation is not capable of altering the Young's modulus of AMCs; ${ }^{14}$ however, these processes can improve the toughness of the composites.

The main concern on the Young's modulus of $e x$ situ AMCs is their tendency to have relatively low ductility and fracture toughness, as shown in Table 7. The damage mechanism of ex-situ AMCs is mainly the reinforcement fracture and decohesion at the matrix/reinforcement interface. To achieve acceptable ductility and toughness, the composition, heat treatment process, size and shape distribution of the reinforcement should be precisely controlled. Also, secondary mechanical deformation will result in an improvement of ductility. In the presence of strong interfacial bonding, effective load transfer from the matrix to the reinforcement is enhanced, leading to good ductility and damage resistance.

\subsection{AMCs with Continuous Reinforcement}

Al alloys reinforced with continuous ceramic reinforcement, such as $\mathrm{SiC}$ and $\mathrm{Al}_{2} \mathrm{O}_{3}$, can be considered as alternative materials to achieve outstanding specific strength and modulus. The $\mathrm{Al} / \mathrm{SiC}_{\mathrm{p}}$ and $\mathrm{Al} /$ $\mathrm{Al}_{2} \mathrm{O}_{3}$ composites can be produced by the molten aluminum infiltration techniques, such as pressureassisted, vacuum-driven, and pressureless or capillarity-driven processes. Aghajanian et al. ${ }^{67,157}$ reported the pressureless infiltration technique, by which the aluminum alloys infiltrated the reinforcement preforms spontaneously in a nitrogen atmosphere. This method is believed to be a cost-effective, nearly net shape technique with the combined processing of 
materials and shaping of the components simultaneously. The basic problem encountered in the fabrication of these composites is the rejection of the ceramic phase by the liquid metal due to their lack of wettability. ${ }^{158}$ To improve the wetting of ceramics by liquid metals, a possible approach is to apply a metal coating on the ceramic particles, which essentially increases the overall surface energy of the solid, thereby promoting wetting by the liquid metal. Although the continuous ceramic reinforcement/fibers can provide $210 \mathrm{GPa}$ Young's modulus, ${ }^{159}$ they usually suffer from very low ductility - less than 0.2 restricting their applications. Moreover, it is difficult to make shaped castings.

\section{Summary and future outlook}

The Young's modulus of aluminum-based materials is one of the most important mechanical properties in controlling structural performance. The improvement of the Young's modulus of castable aluminum-based materials is essential for increasing their competiveness in light weighting structural applications. The capability of making complex shaped castings of these materials is critical in considering the massive production and the application in industry. The castability depends on the introduction methods, processing methods, volume fraction, size, and distribution of the high modulus phases. The influence of alloying elements on the Young's modulus depends on the state. If the alloying elements are in a solid solution phase, the magnitude of the Young's modulus is determined by the nature of the atomic interactions. If the alloying elements form second phases, the magnitude of the Young's modulus is determined by the volume fraction and the intrinsic/modulus of the second phase. Overall, the increase of Young's modulus in conventional cast aluminum alloys is usually less than $15 \%$ through adding alloying elements for manufacturing complex shaped castings. Therefore addition of ceramic particles and reinforcement is necessary for significant improvement of the stiffness of $\mathrm{Al}$ alloys.

The improvement of the Young's modulus through introducing high modulus reinforcement phases as AMCs is an effective approach because of their high Young's modulus. The most capable reinforcement phases are $\mathrm{TiB}_{2}(\mathrm{E}=560 \mathrm{GPa})$ and $\mathrm{SiC}(\mathrm{E}=480 \mathrm{GPa})$ for making shaped castings. Reinforcement phases can be added by ex-situ or in-situ methods, in which the in-situ method with particulate reinforcement is preferred for making castings with relatively complex shape and cavity. The main factors governing the
Young's modulus of AMCs are the volume fraction, aspect ratio, and the interface. The bonding between the matrix and the reinforcement is the most important factor in determining mechanical properties. Strong interfacial bonding provides effective load transfer from the matrix to the reinforcement for improved Young's modulus and other mechanical properties. The main concern on the performance of AMCs is their tendency to have relatively low ductility and fracture toughness when the materials provide high modulus. When using particulate-reinforced AMCs, the castability should be considered due to challenges in casting components with complex shape and cavity. The balance of castability/processibility and the improvement in Young's modulus is the key for further development.

Bimetallic materials, made by metal wires with cast aluminum alloys, are effective for modulus improvement. In fact, bimetallic materials can be considered a special type of composite material. The preforms made by continuous metallic wires as skeletons or frames are a key step. The pretreatment of the surfaces is needed before casting. The overcasting can be any of the conventional casting methods. Knowledge in this area has not been well established for the variety of preform structures, pretreatments, and casting conditions; so continued study is necessary.

Stiff aluminum alloys are potentially one of the most promising materials for the significant reduction of structural weight with satisfied mechanical properties, including the Young's modulus. There are some knowledge gaps and challenges for the further development of high modulus cast aluminum alloys, which include:

a. The Young's modulus of aluminum alloys with multiple components is not fully understood. The development of complex Al-based alloys with the addition of desirable alloying elements is needed to ensure both high modulus and ductility properties.

b. Up to now, the main purpose for the addition of high modulus phase/reinforcement into the $\mathrm{Al}$ alloys has been to improve the wear resistance and high temperature performance. It is very important to carefully and specifically select the type as well as the volume fraction of reinforcement for modulus improvement.

c. Careful selection and combination of desirable alloying elements and in-situ formed reinforcement would possibly be the preferred option for developing the material with dominant stiffness properties, toughness, and good castability. 
potential conflict of interest was reported by the authors.

\section{Funding}

Financial support from Jaguar Land Rover (JLR) [grant number R33232] is gratefully acknowledged.

\section{References}

1. W. S. Miller, L. Zhuang, J. Bottema, A. Wittebrood, P. De Smet, A. Haszler, and A. Vieregge, Recent development in aluminium alloys for the automotive industry, Mater. Sci. Eng. A. 280(1), 7-49 (2000).

2. T. Dursun and C. Soutis, Recent developments in advanced aircraft aluminium alloys, Mater. Des. 56, 862-871 (2014).

3. D. J. Lloyd, Particle reinforced aluminium and magnesium matrix composites, Int. Mater. Rev. 39(1), 1-23 (1994).

4. J. G. Kaufman and E. L. Rooy, Aluminium alloy castings: properties, processes, and applications, ASM International 2004.

5. F. Bonnet, V. Daeschler, and G. Petitgand, High modulus steels: new requirement of automotive market. How to take up challenge?, Can. Metall. Q. 53, 243-252 (2014).

6. V. S. Zolotorevsky, N. A. Belov, and M. V. Glazoff, Casting Aluminium Alloys, Elsevier, Oxford (2007).

7. P. K. Rohatgi, Metal matrix composites, Def. Sci. J. 43(4), 323-349 (2013).

8. A. Mortensen and J. Llorca, Metal matrix composites, Annu. Rev. Mater. Res. 40, 243-270 (2010).

9. S. R. Bakshi, D. Lahiri, and A. Agarwal, Carbon nanotube reinforced metal matrix composites-a review, Int. Mater. Rev. 55, 41-64 (2010).

10. K. L. Kendig and D. B. Miracle, Strengthening mechanisms of an Al-Mg-Sc-Zr alloy, Acta Mater. 50(16), 4165-4175 (2002).

11. K. Masuda-Jindo and K. Terakura, Electronic theory for solid-solution hardening and softening of dilute $\mathrm{Al}$ based alloys: elastic-moduli enhancement of Al-Li alloys, Phys. Rev. B. 39(11), 7509 (1989).

12. W. H. Wang, The elastic properties, elastic models and elastic perspectives of metallic glasses, Prog. Mater. Sci. 57, 487-656 (2012).

13. M. Lucena, J. A. Benito, A. Roca, and J. Jorba, Changes of elastomechanic constants of pure aluminum cold deformed by tension test, Rev. Metal. Madrid. 34, 310-313 (1998).

14. A. Villuendas, J. Jorba, and A. Roca, The role of precipitates in the behavior of Young's modulus in aluminium alloys, Metall. Mater. Trans. A. 45(9), 3857-3865 (2014).

15. I. Polmear, D. St John, J. F. Nie, and M. Qian, Light Alloys: Metallurgy of the Light Metals. ButterworthHeinemann (2017).

16. D. Hull and T. Clyne, An Introduction to Composite Materials, Cambridge University Press (1996).

17. A. Nieto, A. Bisht, D. Lahiri, and A. Agarwal, Graphene reinforced metal and ceramic matrix composites: a review, Int. Mater. Rev. 62, 241-302 (2017).

18. S. C. Tjong and Z. Y. Ma, Microstructural and mechanical characteristics of in situ metal matrix composites, Mater. Sci. Eng. R. 29, 49-113 (2000).

19. I. Ibrahim, F. Mohamed, and E. Lavernia, Particulate reinforced metal matrix composites-a review, J. Mater. Sci. 26, 1137-1156 (1991).

20. R. Jamaati, S. Amirkhanlou, M. R. Toroghinejad, and B. Niroumand, CAR process: a technique for significant enhancement of as-cast MMC properties, Mater. Charac. 62, 1228-1234 (2011).

21. S. Amirkhanlou, R. Jamaati, M. R. Toroghinejad, and $\mathrm{B}$. Niroumand, Manufacturing of high-performance $\mathrm{Al} 356 / \mathrm{SiC}_{\mathrm{p}}$ composite by CAR process, Mater. Manuf. Process. 26, 902-907 (2011).

22. F. Lasagni and H. P. Degischer, Enhanced Young's modulus of Al-Si alloys and reinforced matrices by co-continuous structures, J. Compos. Mater. 44, 739-755 (2010).

23. T. Clyne and J. Mason, The squeeze infiltration process for fabrication of metal-matrix composites, Metall. Trans. A. 18(8), 1519-1530 (1987).

24. M. Acilar and F. Gul, Effect of the applied load, sliding distance and oxidation on the dry sliding wear behaviour of $\mathrm{Al}-10 \mathrm{Si} / \mathrm{SiCp}$ composites produced by vacuum infiltration technique. Mater. Des. 25(3), 209-217 (2004).

25. Y. Zhang, S. Ji, G. Scamans, and Z. Fan, Interfacial characterisation of overcasting a cast $\mathrm{Al}-\mathrm{Si}-\mathrm{Mg}$ (A356) alloy on a wrought Al-Mg-Si (AA6060) alloy, J. Mater. Process. Technol. 243, 197-204 (2017).

26. X. L. Xie, Y. W. Mai, and X. P. Zhou. Dispersion and alignment of carbon nanotubes in polymer matrix: a review, Mater. Sci. Eng. R. 49, 89-112 (2005).

27. H. Porwal, S. Grasso, and M. J. Reece, Review of graphene-ceramic matrix composites, Adv. Appl. Ceram. 112(8), 443-454 (2013).

28. X. Zhang, W. Chen, H. Luo, and T. Zhou, Formation of periodic layered structure between novel $\mathrm{Fe}-\mathrm{Cr}-\mathrm{B}$ cast steel and molten aluminium, Scripta Mate. 130, 288-291 (2017).

29. S. V. Nair, J. K. Tien, and R. C. Bates. Sic-reinforced aluminium metal matrix composites, Inter. Met. Rev. 30(1), 275-290 (1985).

30. T. Christman and S. Suresh, Microstructural development in an aluminium alloy-SiC whisker composite, Acta Metall. 36(7), 1691-1704 (1988). 
31. P. K. Rohatgi, R. Asthana, and S. Das, Solidification, structures, and properties of cast metal-ceramic particle composites, Inter. Met. Rev. 31(1), 115-139 (1986).

32. F. Boland, C. Colin, C. Salmon, and F. Delannay, Tensile flow properties of Al-based matrix composites reinforced with a random planar network of continuous metallic fibres, Acta Mater. 46(18), 6311-6323 (1998).

33. L. Ryelandt, C. Salmon, and F. Delannay, Neutron diffraction analysis of the evolution of phase stresses during plastic straining of aluminium matrix composites reinforced with a continuous, random planar network of fibres, Mater. Sci. Forum. 347-349, 486-491 (2000).

34. Q. Tan, X. Tong, H. Lu, D. Zhang, and J. Hong, Mechanical behaviours of quasi-ordered entangled aluminium alloy wire material, Mater. Sci. Eng. A. 527(1-2), 38-44 (2009).

35. C. Salmon, F. Boland, C. Colin, and F. Delannay, Mechanical properties of aluminium/Inconel 601 composite wires formed by swaging, J. Mater. Sci. 33(23), 5509-5516 (1998).

36. Q. Tan and G. He, 3D entangled wire reinforced metallic composites, Mater. Sci. Eng. A. 546, 233-238 (2012).

37. V. Ganesh, C. Lee, and M. Gupta, Enhancing the tensile modulus and strength of an aluminium alloy using interconnected reinforcement methodology, Mater. Sci. Eng. A. 333(1), 193-198 (2002).

38. C. Salmon, D. Tiberghien, R. Molins, C. Colin, and F. Delannay, Influence of the oxidation conditions of the fibres on the mechanical properties of $\mathrm{Al}$ matrix composites reinforced with Ni-based fibres, Mater. Sci. Forum. 369-372, 435-442 (2001).

39. C. Salmon, C. Colin, R. Molins, and F. Delannay, Strengthening of $\mathrm{Al} / \mathrm{Ni}$-based composites by in situ growth of intermetallic particles, Mater. Sci. Eng. A. 334(1), 193-200 (2002).

40. M. Gupta, M. O. Lai, and C. Y. H. Lim, Development of a novel hybrid aluminium-based composite with enhanced properties, J. Mater. Process Technol. 176(1-3), 191-199 (2006).

41. F. Boland, C. Colin, and F. Delannay, Control of interfacial reactions during liquid phase processing of aluminium matrix composites reinforced with INCONEL 601 fibers, Metall. Mater. Trans. A. 29(6), 1727-1739 (1998).

42. K. Guler, A. Kisasoz, and A. Karaaslan, Investigation of $\mathrm{Al} /$ Steel bimetal composite fabrication by vacuum assisted solid mould investment casting, Acta Phys Polonica A. 126(6), 1327-1330 (2014).

43. J. Viala, M. Peronnet, F. Barbeau, F. Bosselet, and J. Bouix, Interface chemistry in aluminium alloy castings reinforced with iron base inserts, Compos. Part A. 33, 1417-1420 (2002).

44. V. Ganesh and M. Gupta, Effect of the extent of reinforcement interconnectivity on the properties of an aluminium alloy, Scripta Mater. 44(2), 305-310 (2001).

45. S. Manasijevic, R. Radiša, Z. Z. Brodarac, N. Dolić, and M. Djurdjevic, Al-Fin bond in aluminium piston alloy \& austenitic cast iron insert, Int. J. Met. 9, 27-32 (2015).

46. F. Haddadi, Microstructure reaction control of dissimilar automotive aluminium to galvanized steel sheets ultrasonic spot welding, Mater. Sci. Eng. A. 678, 72-84 (2016).

47. O. Dezellus, B. Digonnet, M. Sacerdote-Peronnet, F. Bosselet, D. Rouby, and J. C. Viala, Mechanical testing of steel/aluminium-silicon interfaces by pushout, Int. J. Adhes. 27, 417-421 (2007).

48. A. Bouayad, C. Gerometta, A. Belkebir, and A. Ambari, Kinetic interactions between solid iron and molten aluminium, Mater. Sci. Eng. A. 363, 53-61 (2003).

49. S. Kobayashi and T. Yakou, Control of intermetallic compound layers at interface between steel and aluminium by diffusion-treatment, Mater. Sci. Eng. A. 338, 44-53 (2002).

50. K. Zhang, X. Bian, Y. Li, Y. Liu, and C. Yang, New evidence for the formation and growth mechanism of the intermetallic phase formed at the $\mathrm{Al} / \mathrm{Fe}$ interface, J. Mater. Res. 95, 3279-3287 (2013).

51. M. R. Arghavani, M. Movahedi, and A. H. Kokabi, Role of zinc layer in resistance spot welding of aluminium to steel, Mater. Des. 102, 106-114 (2016).

52. Y. Liu, X. Bian, K. Zhang, C. Yang, L. Feng, H. S. Kim, and J. Guo, Interfacial microstructures and properties of aluminium alloys/galvanized low-carbon steel under high-pressure torsion, Mater. Des. 64, 287-293 (2014).

T. Liu, Q. Wang, Y. Sui, et An investigation into aluminium-aluminium bimetal fabrication by squeeze casting, Mater. Des. 68, 8-17 (2015).

54. M. Schwankl, J. Wedler, and C. Körner, Wrought $\mathrm{Al}$-Cast $\mathrm{Al}$ compound casting based on zincate treatment for aluminium wrought alloy inserts, J. Mater. Process. Technol. 238, 160-168 (2016).

55. S. L. Pramod, S. R. Bakshi, and B. S. Murty, Aluminum-based cast in situ composites: a review, J. Mater. Eng. Perform. 24, 2185-2207 (2015).

56. S. Amirkhanlou and B. Niroumand, Fabrication and characterization of $\mathrm{Al} 356 / \mathrm{SiC}_{\mathrm{p}}$ semisolid composites by injecting $\mathrm{SiC}_{\mathrm{p}}$ containing composite powders, $J$. Mater. Process. Technol. 212, 841-847 (2012).

57. S. S. Sidhu, S. Kumar, and A. Batish. Metal matrix composites for thermal management: a review, Crit. Rev. Solid State Mater. Sci. 4, 132-157 (2016).

58. B. V. Ramnath, C. Elanchezhian, R. M. Annamalai, S. Aravind, T. S. A. Atreya, V. Vignesh, and C. Subramanian, Aluminium metal matrix composites a review. Rev Adv Mater Sci. 2014;38:55-60.

59. K. Tian, Y. Zhao, L. Jiao, S. Zhang, Z. Zhang, and X. $\mathrm{Wu}$, Effects of in situ generated $\mathrm{ZrB}_{2}$ nano-particles on microstructure and tensile properties of $2024 \mathrm{Al}$ matrix composites, J. Alloys Comp. 594, 1-6 (2014).

60. R. Jamaati, S. Amirkhanlou, M. R. Toroghinejad, and B. Niroumand, Comparison of the microstructure and mechanical properties of as-cast $\mathrm{A} 356 / \mathrm{SiC}$ MMC processed by ARB and CAR methods, $J$. Mater. Eng. Perform. 21(7), 1249-1253 (2012).

61. K. U. Kainer, Basics of Metal Matrix Composites in Book: Metal Matrix Composites: Custom-made 
Materials for Automotive and Aerospace Engineering, 1-54 (2006).

62. K. K. Chawla, Metal Matrix Composites, Wiley Online Library (2006).

63. J. Zhang and Z. Fan, Microstructure and mechanical properties of in situ $\mathrm{Al}-\mathrm{Mg}_{2} \mathrm{Si}$ composites. Mater. Sci. Technol. 16(7-8), 913-918 (2000).

64. K. U. Kainer, Metal Matrix Composites: Custommade Materials for Automotive and Aerospace Engineering, John Wiley \& Sons (2006).

65. J. Mathew, A. Mandal, and S. D. Kumar, Effect of semi-solid forging on microstructure and mechanical properties of in-situ cast $\mathrm{Al}-\mathrm{Cu}-\mathrm{TiB}_{2}$ composites, $J$. Alloys Comp. 712, 460-467 (2017).

66. Z. Fan, Y. Wang, Y. Zhang, T. Qin, X. R. Zhou, G. E. Thompson, T. Pennycook, and T. Hashimoto, Grain refining mechanism in the $\mathrm{Al} / \mathrm{Al}-\mathrm{Ti}-\mathrm{B}$ system, Acta Mater. 84, 292-304 (2015).

67. M. K. Aghajanian, M. A. Rocazella, J. T. Burke, and S. D. Keck, The fabrication of metal matrix composites by a pressureless infiltration technique. $J$. Mater. Sci. 26(2), 447-454 (1991).

68. S. V. Prasad, and R. Asthana, Aluminium metalmatrix composites for automotive applications: tribological considerations, Tribol. Lett. 17(3), 445-453 (2004).

69. S. Amirkhanlou and B. Niroumand, Development of $\mathrm{Al} 356 / \mathrm{SiC}_{\mathrm{p}}$ cast composites by injection of $\mathrm{SiC}_{\mathrm{p}}$ containing composite powders, Mater. Des. 32(4), 1895-1902 (2011).

70. S. Amirkhanlou and B. Niroumand, Effects of reinforcement distribution on low and high temperature tensile properties of $\mathrm{Al} 356 / \mathrm{SiC}_{\mathrm{p}}$ cast composites produced by a novel reinforcement dispersion technique. Materi. Sci. Eng. A. 528(24), 7186-7195 (2011).

71. L. A. Jacobson and J. McKittrick, Rapid solidification processing, Mater. Sci. Eng. R. 11(8), 355-408 (1994).

72. M. Asta, C. Beckermann, and A. Karma, Solidification microstructures and solid-state parallels: recent developments, future directions. Acta Mater. 57(4), 941-971 (2009).

73. K. M. Sree Manu, S. Arun Kumar, T. P. D. Rajan, M. Riyas Mohammed, and B. C. Pai, Effect of alumina nanoparticle on strengthening of Al-Si alloy through dendrite refinement, interfacial bonding and dislocation bowing, J. Alloys Comp. 712, 394-405 (2017).

74. M. L. Ted Guo and C. Y. Tsao, Tribological behaviour of aluminium/SiC/nickel-coated graphite hybrid composites. Mater. Sci. Eng. A. 333, 134-145 (2002).

75. P. K. Rohatgi, K. Pasciak, C. S. Narendranath, et al. Evolution of microstructure and local thermal conditions during directional solidification of A356-SiC particle composites. J. Mater. Sci. 29(20), 5357-5366 (1994).

76. D. Zhao, F. R. Tuler, and D. J. Lloyd, Fracture at elevated temperatures in a particle reinforced composite. Acta Metall. Mater. 42(7), 2525-2533 (1994).

77. Z. Asghar, G. Requena, and E. Boller, Three-dimensional rigid multiphase networks providing high- temperature strength to cast $\mathrm{AlSi} 10 \mathrm{Cu} 5 \mathrm{Ni1}-2$ piston alloys, Acta Mater. 59(16), 6420-6432 (2011).

78. H. Springer, R. Aparicio Fernandez, M. J. Duarte, et al. Microstructure refinement for high modulus in-situ metal matrix composite steels via controlled solidification of the system Fe-TiB2, Acta Mater. 96, 47-56 (2015).

79. H. Zhang, H. Springer, R. Aparicio-Fernandez, et al. Improving the mechanical properties of $\mathrm{Fe}-\mathrm{TiB}_{2}$ high modulus steels through controlled solidification processes, Acta Mater. 118, 187-195 (2016).

80. Q. Gao, et Improvement of particles distribution of in-situ 5 vol\% $\mathrm{TiB}_{2}$ particulates reinforced Al-4.5 $\mathrm{Cu}$ alloy matrix composites with ultrasonic vibration treatment, J. Alloys Comp. 692, 1-9 (2017).

81. Q. Gao, et al. Preparation of in-situ $5 \mathrm{vol} \% \mathrm{TiB}_{2}$ particulate reinforced $\mathrm{Al}-4.5 \mathrm{Cu}$ alloy matrix composites assisted by improved mechanical stirring process, Mater. Des. 94, 79-86 (2016).

82. G. R. Liu. A step-by-step method of rule-of-mixture of fiber-and particle-reinforced composite materials, Compos. Struct. 40, 313-322 (1997).

83. J. C. Halpin and J. L. Kardos. The Halpin-Tsai equations: a review. Polymer Eng. Sci. 16, 344-352 (1976).

84. Z. Hashin and S. Shtrjkman, A variational approach to the theory of the elastic behaviour of multiphase materials. J. Mech. Phys. Solids. 11, 127-140 (1963).

85. L. Tuchinskii, Elastic constants of pseudoalloys with a skeletal structure, Powder Metall. Met. Ceram. 22, 588-595 (1983).

91. H. Peng, A review of consolidation effects on tensile properties of an elemental $\mathrm{Al}$ matrix composite. Mater. Sci. Eng. A. 396, 1-2 (2005).

87. H. B. Michael Rajan, S. Ramabalan, I. Dinaharan, and S. J. Vijay, Synthesis and characterization of in situ formed titanium diboride particulate reinforced AA7075 aluminum alloy cast composites, Mater. Des. 44, 438-445 (2013)

88. Z. Liu, et al. Effect of ultrasonic vibration on microstructural evolution of the reinforcements and degassing of in situ $\mathrm{TiB}_{2 \mathrm{p}} / \mathrm{Al}-12 \mathrm{Si}-4 \mathrm{Cu}$ composites, J. Mater. Process. Technol. 212(2), 365-371 (2012).

89. J. Geng, et al. The solution treatment of in-situ submicron $\mathrm{TiB}_{2} / 2024 \mathrm{Al}$ composite, Mater. Des. 98, 186-193 (2016).

90. T. Hong, Y. Shen, J. Geng, et al. Effect of cryogenic pre-treatment on aging behavior of in-situ $\mathrm{TiB}_{2} /$ Al-Cu-Mg composites, Mater. Charac. 119, 40-46 (2016).

91. K. Tee, L. Lu, and M. Lai, In situ stir cast $\mathrm{Al}_{-} \mathrm{TiB}_{2}$ composite: processing and mechanical properties, Mater. Sci. Technol. 17(2), 201-206 (2001).

92. K. L. Tee, L. Lu, and M. Lai, In situ processing of $\mathrm{Al}-\mathrm{TiB}_{2}$ composite by the stir-casting technique, $J$. Mater. Process. Technol. 89, 513-519 (1999).

93. K. Tee, L. Lu, and M. Lai, Synthesis of in situ Al$\mathrm{TiB}_{2}$ composites using stir cast route, Compos. Struct. 47(1), 589-593 (1999).

94. A. Changizi, A. Kalkanli, and N. Sevinc, Production of in situ aluminium-titanium diboride master alloy 
formed by slag-metal reaction, J. Alloys Comp. 509(2), 237-240 (2011).

95. L. Lü, et al. In situ $\mathrm{TiB}_{2}$ reinforced $\mathrm{Al}$ alloy composites, Scripta Mater. 45(9), 1017-1023 (2001).

96. J. Mathew, et X-ray tomography studies on porosity and particle size distribution in cast in-situ Al$\mathrm{Cu}-\mathrm{TiB}_{2}$ semi-solid forged composites, Mater. Charact. 118, 57-64 (2016).

97. A. Mandal, M. Chakraborty, and B. Murty, Ageing behaviour of A356 alloy reinforced with in-situ formed $\mathrm{TiB}_{2}$ particles, Mater. Sci. Eng. A. 489(1), 220-226 (2008).

98. C. Feng and L. Froyen, Microstructures of in situ Al/ $\mathrm{TiB}_{2}$ MMCs prepared by a casting route, J. Mater. Sci. 35(4), 837-850 (2000).

99. X. H. Chen and H. Yan, Solid-liquid interface dynamics during solidification of $\mathrm{Al} 7075-\mathrm{Al}_{2} \mathrm{O}_{3 \mathrm{np}}$ based metal matrix composites, Mater. Des. 94, 148-158 (2016).

100. Z. Chen, et al. Development of $\mathrm{TiB}_{2}$ reinforced aluminium foundry alloy based in situ composites Part I: an improved halide salt route to fabricate Al$5 \mathrm{wt} \% \mathrm{TiB}_{2}$ master composite, Mater. Sci. Eng. A. 605, 301-309 (2014).

101. A. Mandal, B. Murty, and M. Chakraborty, Sliding

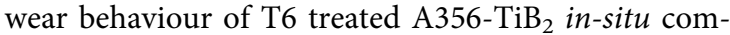
posites, Wear. 266(7), 865-872 (2009).

103. S. Amirkhanlou, S. Ji, Y. Zhang, et al. High modulus $\mathrm{Al}-\mathrm{Si}-\mathrm{Mg}-\mathrm{Cu} / \mathrm{Mg}_{2} \mathrm{Si}-\mathrm{TiB}_{2}$ hybrid nanocomposite: microstructural characteristics and micromechanicsbased analysis, J. Alloy Compd. 694, 313-324 (2017).

106. A. Westwood, Materials for advanced studies and devices. Metall. Trans. A. 19(4), 749-758 (1988).

107. G. Li, M. Zheng, and G. Chen, Mechanism and kinetic model of in-situ $\mathrm{TiB}_{2} / 7055 \mathrm{Al}$ nanocomposites synthesized under high intensity ultrasonic field, J. Wuhan Uni. Technol. Mater. Sci. Ed. 26(5), 920-925 (2011).

102. S. Kumar, et al. Tensile and wear behaviour of in situ $\mathrm{Al}-7 \mathrm{Si} / \mathrm{TiB}_{2}$ particulate composites, Wear. 265(1), 134-142 (2008).

108. G. Han, et al. High-temperature mechanical properties and fracture mechanisms of Al-Si piston alloy reinforced with in situ $\mathrm{TiB}_{2}$ particles, Mater. Sci. Eng. A. 633, 161-168 (2015).

104. S. Kumar, V. S. Sarma, and B. Murty, Effect of temperature on the wear behaviour of $\mathrm{Al}-7 \mathrm{Si}-\mathrm{TiB}_{2}$ insitu composites, Metall. Mater. Trans. A. 40(1), 223-231 (2009).

105. M. Wang, et al. Mechanical properties of in-situ $\mathrm{TiB}_{2} / \mathrm{A} 356$ composites, Mater. Sci. Eng. A. 590, 246-254 (2014).

109. R. Chang and L. J. Graham, Low-temperature elastic properties of $\mathrm{ZrC}$ and TiC, J. Applied Phys. 37(10), 3778-3783 (1966).

110. W. Jiang, et al. Synthesis of $\mathrm{TiC} / \mathrm{Al}$ composites in liquid aluminium, Mater. Lett. 32(2), 63-65 (1997).

111. K. J. Lijay, et al. Microstructure and mechanical properties characterization of AA6061/TiC aluminium matrix composites synthesized by in situ reaction of silicon carbide and potassium fluotitanate, Trans. Nonferrous Met. Soc. China. 26(7), 1791-1800 (2016).
112. J. J. Moses, I. Dinaharan, and S. J. Sekhar, Prediction of influence of process parameters on tensile strength of AA6061/TiC aluminum matrix composites produced using stir casting, Trans. Nonferrous Met. Soc. China. 26, 1498-1511 (2016).

113. Y. Liang, J. Zhou, and S. Dong, Microstructure and tensile properties of in situ $\mathrm{TiC}_{\mathrm{p}} / \mathrm{Al}-4.5 \mathrm{wt} . \% \mathrm{Cu}$ composites obtained by direct reaction synthesis, Mater. Sci. Eng. A. 527(29), 7955-7960 (2010).

114. Z. Liu, et al. Synthesis of submicrometer-sized TiC particles in aluminium melt at low melting temperature, J. Mater. Res. 29(7), 896-901 (2014).

115. P. Li, E. Kandalova, and V. Nikitin, In situ synthesis of $\mathrm{Al}-\mathrm{TiC}$ in aluminium melt, Mater. Lett. 59(19), 2545-2548 (2005).

117. R. Tyagi, Synthesis and tribological characterization of in situ cast Al-TiC composites, Wear. 259(1), 569-576 (2005).

116. B. Yang, G. Chen, and J. Zhang, Effect of Ti/C additions on the formation of $\mathrm{Al}_{3} \mathrm{Ti}$ of in situ $\mathrm{TiC} / \mathrm{Al}$ composites, Mater. Des. 22(8), 645-650 (2001).

118. N. Samer, et $\mathrm{d}_{\text {. }}$ Microstructure and mechanical properties of an $\mathrm{Al}-\mathrm{TiC}$ metal matrix composite obtained by reactive synthesis, Compos. Part A. 72, 50-57 (2015).

119. S. Mohapatra, et al. Fabrication of Al-TiC composites by hot consolidation technique: its microstructure and mechanical properties, J. Mater. Res. Technol. 5(2), 117-122 (2016).

121. A. P. Amosov, A. Luts, and A. Ermoshkin, Nanostructured aluminium matrix composites of Al$10 \% \mathrm{TiC}$ obtained in situ by the SHS method in the melt, Key Eng. Mater. 684, 281-286 (2016).

122. Z. Hashin and S. Shtrikman, A variational approach to the elastic behaviour of multiphase materials, $J$. Mech. Phys. Solid. 11, 127-140 (1962).

123. X. Tong and H. Fang, Al-TiC composites in situprocessed by ingot metallurgy and rapid solidification technology: Part II. Mechanical behaviour, Metall. Mater. Trans. A. 29(3), 893-902 (1998).

120. A. Kumar, P. Jha, and M. Mahapatra, Abrasive wear behaviour of in Situ $\mathrm{TiC}$ reinforced with $\mathrm{Al}-4.5 \% \mathrm{Cu}$ matrix, J. Mater. Eng. Perform. 23(3), 743-752 (2014).

124. S. Amirkhanlou and B. Niroumand, Synthesis and characterization of 356-SiCp composites by stir casting and compocasting methods, Trans. Nonferrous Met. Soc. China. 20, s788-s793 (2010).

125. S. Amirkhanlou, R. Jamaati, B. Niroumand, and M. R. Toroghinejad, Using ARB process as a solution for dilemma of $\mathrm{Si}$ and $\mathrm{SiC}_{\mathrm{p}}$ distribution in cast $\mathrm{Al}-\mathrm{Si} / \mathrm{SiC}_{\mathrm{p}}$ composites, J. Mater. Process. Technol. 211, 1159-1165 (2011).

126. J. C. Lee, J. Y. Byun, S. B. Park, al. Prediction of Si contents to suppress the formation of $\mathrm{Al}_{4} \mathrm{C}_{3}$ in the $\mathrm{SiC}_{\mathrm{p}} / \mathrm{Al}$ composite, Acta Mater. 46(5), 1771-1780 (1998).

127. S. Amirkhanlou and B. Niroumand, Microstructure and mechanical properties of $\mathrm{Al} 356 / \mathrm{SiC}_{\mathrm{p}}$ cast composites fabricated by a novel technique, J. Mater. Eng. Perform. 22(1), 85-93 (2012).

128. Z. Peng and L. Fuguo, Effects of particle clustering on the flow behaviour of $\mathrm{SiC}$ particle reinforced $\mathrm{Al}$ 
metal matrix composites, Rare Met. Mater. Eng. 39(9), 1525-1531 (2010).

129. S. Balasivanandha Prabhu, L. Karunamoorthy, S. Kathiresan, et al. Influence of stirring speed and stirring time on distribution of particles in cast metal matrix composite, Mater. Process. Technol. 171, 268-273 (2006).

130. S. Tzamtzis, N. S. Barekar, N. Hari Babu, al. Processing of advanced $\mathrm{Al} / \mathrm{SiC}$ particulate metal matrix composites under intensive shearing-A novel Rheo-process, Compos. Part A. 40, 144-151 (2009).

131. A. H. Properties, Selection: Nonferrous Alloys and Special-purpose Materials, vol. 2, ASM International, Materials, Park, OH (1990).

132. B. A. Kumar and N. Murugan, Metallurgical and mechanical characterization of stir cast AA6061-

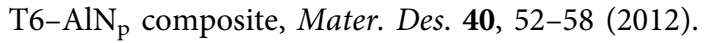

133. $\mathrm{P}$. $\mathrm{Yu}$, al. In situ fabrication and mechanical properties of Al-AlN composite by hot extrusion of partially nitrided AA6061 powder, J. Mater. Res. 26(14), 1719-1725 (2011).

134. C. Yang, at. Microstructure and mechanical properties of AlN particles in situ reinforced $\mathrm{Mg}$ matrix composites, Mater. Sci. Eng. A. 674, 158-163 (2016).

135. Q. Hou, R. Mutharasan, and M. Koczak, Feasibility of aluminium nitride formation in aluminium alloys, Mater. Sci. Eng. A. 195, 121-129 (1995).

136. Q. Zheng and R. Reddy, Mechanism of in situ formation of $\mathrm{AlN}$ in $\mathrm{Al}$ melt using nitrogen gas, $J$. Mater. Sci. 39(1), 141-149 (2004).

137. S. S. Kumari, U. Pillai, and B. Pai, Synthesis and characterization of in situ Al-AlN composite by nitrogen gas bubbling method, J. Alloy Compd. 509(5), 2503-2509 (2011).

138. Q. Zheng and R. G. Reddy, Kinetics of in-situ formation of AlN in $\mathrm{Al}$ alloy melts by bubbling ammonia gas, Metall. Mater. Trans. B. 34(6), 793-804 (2003).

139. M. Chedru, J. L. Chermant, and/J. Vicens, Thermal properties and Young's modulus of Al-AlN composites, J. Mater. Sci. Lett. 20, 893-895 (2001).

140. M. Balog, P. Krizik, M. Yan, et al. SAP-like ultrafine-grained $\mathrm{Al}$ composites dispersion strengthened with nanometric AlN, Mater. Sci. Eng. A. 588, 181-187 (2013).

141. I. Dinaharan, N. Murugan, and S. Parameswaran, Influence of in situ formed $\mathrm{ZrB}_{2}$ particles on microstructure and mechanical properties of AA6061 metal matrix composites, Mater. Sci. Eng. A. 528(18), 5733-5740 (2011).

142. S. L. Zhang, et al. Fabrication and dry sliding wear behaviour of in situ $\mathrm{Al}-\mathrm{K}_{2} \mathrm{ZrF}_{6}-\mathrm{KBF}_{4}$ composites reinforced by $\mathrm{Al}_{3} \mathrm{Zr}$ and $\mathrm{ZrB}_{2}$ particles, J. Alloy Compd. 450(1), 185-192 (2008).

144. Y. Zhao, et al. Effects of molten temperature on the morphologies of in situ $\mathrm{Al}_{3} \mathrm{Zr}$ and $\mathrm{ZrB}_{2}$ particles and wear properties of $\left(\mathrm{Al}_{3} \mathrm{Zr}+\mathrm{ZrB}_{2}\right) / \mathrm{Al}$ composites, Mater. Sci. Eng. A. 457(1), 156-161 (2007).

145. D. Zhao, et al. In-situ preparation of Al matrix composites reinforced by $\mathrm{TiB}_{2}$ particles and sub-micron $\mathrm{ZrB}_{2}$, J. Mater. Sci. 40(16), 4365-4368 (2005).
146. N. Rengasamy, M. Rajkumar, and S. S. Kumaran, An analysis of mechanical properties and optimization of EDM process parameters of Al 4032 alloy reinforced with $\mathrm{ZrB}_{2}$ and $\mathrm{TiB}_{2}$ in-situ composites, J. Alloy Compd. 662, 325-338 (2016).

147. A. Mahamani, et al. Synthesis, quantitative elemental analysis, microstructure characteristics and micro hardness analysis of AA2219 aluminium alloy matrix composite reinforced by in-situ $\mathrm{TiB}_{2}$ and sub-micron $\mathrm{ZrB}_{2}$ particles, Frontiers Auto Mech. Eng. 25, 50-53 (2010).

143. S. Zhang, Y. Zhao, G. Chen, and X. Cheng, Microstructures and dry sliding wear properties of in situ $\left(\mathrm{Al}_{3} \mathrm{Zr}+\mathrm{ZrB}_{2}\right) / \mathrm{Al}$ composites, J. Mater. Process. Technol. 184, 201-208 (2007).

148. I. Dinaharan and N. Murugan, Dry sliding wear behaviour of $\mathrm{AA} 6061 / \mathrm{ZrB}_{2}$ in-situ composite, Trans. Nonferrous Met. Soci. China. 22(4), 810-818 (2012).

149. G. N. Kumar, et al. Dry sliding wear behaviour of AA $6351-\mathrm{ZrB}_{2}$ in situ composite at room temperature, Mater. Des. 31(3), 1526-1532 (2010).

150. J. D. R. Selvam and I. Dinaharan, In situ formation of $\mathrm{ZrB}_{2}$ particulates and their influence on microstructure and tensile behaviour of AA7075 aluminium matrix composites, Eng. Sci. Technol. Inter. J. 20(1), 187-196 (2017).

151. G. Gautam, et al. High temperature tensile and tribological behaviour of hybrid $\left(\mathrm{ZrB}_{2}+\mathrm{Al}_{3} \mathrm{Zr}\right)$ / AA5052 in situ composite, Metall. Mater. Trans. A. 47(9), 4709-4720 (2016).

152. G. Gautam and A. Mohan, Effect of $\mathrm{ZrB}_{2}$ particles on the microstructure and mechanical properties of hybrid $\left(\mathrm{ZrB}_{2}+\mathrm{Al}_{3} \mathrm{Zr}\right) / \mathrm{AA} 5052$ in situ composites, J. Alloy Compd. 649, 174-183 (2015).

153. K. Wang, et al. Fabrication of in situ AlN-TiN/Al inoculant and its refining efficiency and reinforcing effect on pure aluminium, J. Alloy Compd. 547, 5-10 (2013).

154. Y. Zhang, N. Ma, and H. Wang, Improvement of yield strength of LM24 alloy, Mater. Des. 54, 14-17 (2014).

155. S. Amirkhanlou, M. R. Rezaei, B. Niroumand, and M. R. Toroghinejad, High-strength and highly-uniform composites produced by compocasting and cold rolling processes, Mater. Des. 32, 2085-2090 (2011).

156. P. D. Lee and J. D. Hunt, Hydrogen porosity in directional solidified aluminium-copper alloys: in situ observation, Acta Mater. 45(10), 4155-4169 (1997).

157. M. K. Aghajanian, J. Burke, D. R. White, et al. A new infiltration process for the fabrication of metal matrix composites, SAMPE Quarterly. 20, 43-46 (1989).

158. J. Chen, C. Hao, and J. Zhang, Fabrication of 3D$\mathrm{SiC}$ network reinforced aluminium-matrix composites by pressureless infiltration, Mater. Lett. 60, 2489-2492 (2006).

159. G. S. Daehn, B. Starck, and L. Xu, Elastic and plastic behaviour of a co-continuous alumina/aluminium composite, Acta Mater. 44, 249-261 (1996).

160. B. Basu and K. Balani. Advanced Structural Ceramics. John Wiley \& Sons (2011).
2066

2067

2068

2069

2070

2071

2072

2073

2074

2075

2076

2077

2078

2079

2080

2081

2082

2083

2084

2085

2086

2087

2088

2089

2090

2091

2092

2093

2094

2095

2096

2097

2098

2099

2100

2101

2102

2103

2104

2105

2106

2107

2108

2109

2110

2111

2112

2113

2114

2115

2116 